\title{
KWESTIA CHRONOLOGII, TYPOLOGII I POCHODZENIA SZKLANEJ BIŻUTERII Z WCZESNOŚREDNIOWIECZNEGO OŚRODKA GRODOWEGO W GNIEŹNIE
}

\author{
THE ISSUE OF CHRONOLOGY, TYPOLOGY AND ORIGIN \\ OF GLASS JEWELRY \\ FROM THE EARLY MEDIEVAL SETTLEMENT IN GNIEZNO
}

\author{
Joanna Sawicka \\ https://orcid.org/0000-0001-5515-892X \\ Ośrodek Studiów Pradziejowych i Średniowiecznych IAE PAN, Poznań \\ sawicka@man.poznan.pl
}

\begin{abstract}
The study presents 175 artefacts from the settlement center in Gniezno - beads and rings. The materials come from settlement levels from around the mid-10th to the 13th centuries. The latest chronological findings based on $14 \mathrm{C}$ dating have made it possible to refine the dating, especially of the early settlement levels of the stronghold, where the vast majority of glass artefacts come from. Three basic groups of beads have been distinguished based on the technique of their production - beads made of a drawing a tube, the technique of winding a glass strip, as well as casting and sintering. The results of 7 physico-chemical analyzes of the glass composition (performed with the X-Ray Fluorescence, XRF method) are presented. Physicochemical analyzes of the chemical composition of the tested beads made it possible to determine the technological group and the type of glass. An attempt was made to explain the origin of the starting material (glass) for jewelery. A comparative analysis made it possible to indicate in a general manner possible manufacturers and to outline the likely directions of the influx of these glass ornaments to Gniezno.
\end{abstract}

KEY WORDS: early Middle Ages, settlement, Gniezno, glass, beads, rings, sodium glass, lead glass, chronology, origin

Uchwycenie zachodzących zmian w występowaniu zabytków szklanych we wczesnym średniowieczu w gnieźnieńskim ośrodku grodowym jest zadaniem złożonym. Zaburzenia stratygrafii, powstałe na przestrzeni wieków w wyniku realizacji różnego rodzaju inwestycji, spowodowały trudności z określeniem datowania warstw 
kulturowych. Brak zaginionej w czasie ostatniej wojny części dokumentacji z badań prowadzonych w latach 1936/1937-1938 na stanowisku 13b (III podgrodzie zespołu grodowego) dodatkowo utrudnia wszelkie opracowania archeologiczne. Materiały wykopaliskowe z tak znaczącego ośrodka, jakim było Gniezno w okresie wczesnego średniowiecza, najczęściej nie miały pierwszorzędnych walorów poznawczych. Dotyczy to także wyrobów szklanych. Należy jednak dodać, że biżuteria szklana z ziem polskich rzadko jest wyznacznikiem chronologicznym. W sposób ograniczony przystają do naszych realiów próby datowania zespołami bądź pojedynczymi znaleziskami szklanych przedmiotów, przede wszystkim paciorków (np. Callmer, 1997 oraz Delvaux, 2017).

Podjęta w niniejszym opracowaniu próba uchwycenia zależności między ustaleniami chronologicznymi, typologicznymi i w mniejszym stopniu proweniencji tego rodzaju wyrobów oparta jest przede wszystkim na najnowszych ustaleniach dotyczących datowania gnieźnieńskiego zespołu grodowego. Te najnowsze są oparte na badaniach radiowęglowych ${ }^{14} \mathrm{C}$ prób związanych z treścią kulturową, zawierającą m.in. wyroby szklane ${ }^{1}$.

Badania archeologiczne na Górze Lecha w Gnieźnie prowadzono od końca 1936 roku (tzw. podgrodzie III, część zachodnia, stan. 13b), a po wojnie wznowiono je w roku 1948 (tzw. podgrodzie I, część zachodnia, stan. 15c) i są one kontynuowane z niewielkimi przerwami do chwili obecnej. Prace te dostarczyły znacznej liczby wyrobów ze szkła przechowywanych w Muzeum Początków Państwa Polskiego w Gnieźnie oraz w Muzeum Archeologicznym w Poznaniu (część materiałów z badań z lat 1936/1937-1938, ze stan. 13b). Cały zbiór zabytków ze szkła obejmuje ok. 600 pozycji, w tym zbiór biżuterii - 175 okazów. Warto wspomnieć, że oprócz biżuterii odkryto także pozostałości oszkleń (bliżej Sawicka, 2018a).

Przedstawione niżej ustalenia dotyczą biżuterii odkrytej na 6 stanowiskach położonych w obrębie wczesnośredniowiecznego zespołu grodowego na Górze Lecha w Gnieźnie i na terenach bezpośrednio do niego przylegających (ryc. 1):

- stan. 13b - III podgrodzie, najmłodszy człon zespołu grodowego, zostało otoczone drewniano-ziemnymi wałami odcinkowymi dopiero w 1 ćwierci XI w. Wcześniej, w wieku X, teren ten grodziły częstokoły o przebiegu zbliżonym do późniejszych umocnień drewniano-ziemnych. Ze stanowiska 13b, badanego w latach 1936/1937-1938, pochodzi zdecydowana większość zaprezentowanego poniżej materiału (162 paciorki i jedno kółko). Według ustaleń Tadeusza Wieczorkowskiego (1939, s. 117-118), poza kilkoma okazami, odkryto je przede wszystkim w warstwach VI-VIII, obecnie datowanych na okres od połowy X do pierwszej poł. XI w.:

${ }^{1}$ Projekt badawczy NPRH nr 11H 130216 82: Uściślenie i weryfikacja chronologii oraz periodyzacji grodów tzw. centralnych monarchii pierwszych Piastów (Gniezno, Poznań, Giecz) na podstawie akceleratorowych datowań radiowęglowych, kierownik prof. Michał Kara. 


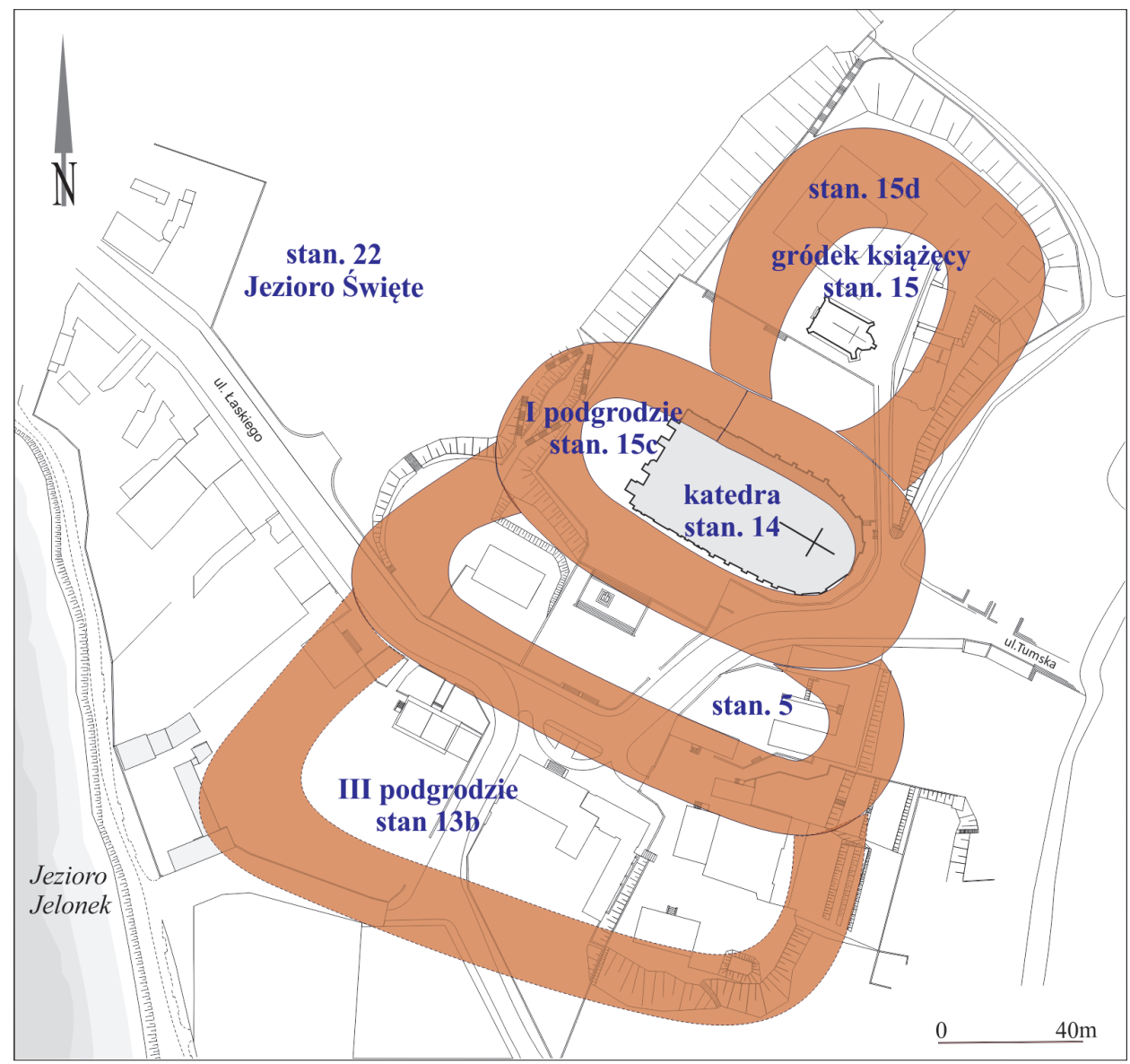

Ryc. 1. Gniezno, Góra Lecha. Gród gnieźnieński w X-XIII w. (ryc. Ł. Ranoszek, J. Sawicka)

Fig. 1. Gniezno, Lech Mountain. Gniezno stronghold in the 10th-13th centuries (fig. Ł. Ranoszek, J. Sawicka)

- stan. 5 - wschodnia część podgrodzia II. Tu m.in. zarejestrowano niewielkie silnie zniszczone cmentarzysko wczesnośredniowieczne (późnej fazy?). $\mathrm{Z}$ omawianego stanowiska pochodzi jeden fragment kółka;

- stan. 14 - teren tzw. podgrodzia I (część centralna) zajmowany obecnie przez katedrę, a wcześniej przez kolejne świątynie romańskie. Ze stanowiska 14 pod katedrą - zyskano z warstw rumoszowych jeden fragment kółka i 4 paciorki;

- stan. 15c (dawne stan.2) - obszar położony w obrębie grodu (tzw. podgrodzia I) w północno-zachodnim sąsiedztwie katedry. W warstwie o zaburzonej stratygrafii odkryto dwa fragmenty kółek;

- stan. 15 (15d) - teren książęcego grodu wydzielonego w północnej części Góry Lecha. Na stanowisku tym odkryto 2 paciorki i fragm. kółka; 
- stan. 22 (dawne Jezioro Święte), część brzegowa jeziora na zachodnim przedłużeniu osi katedry (grodu), u podnóża wału obronnego. Z warstw rumoszowych pochodzi jeden paciorek;

- stan. 77 - osada i cmentarzysko z XII-XIII w. przy ul. św. Wawrzyńca, przy kościele pod tym samym wezwaniem, leżące poza obszarem ścisłego zespołu grodowego. $Z$ wielowarstwowego cmentarzyska pochodzi luźne znalezisko paciorka.

Badania analityczne szklanych wyrobów prowadzono zgodnie z przyjętą przez badaczy szkła procedurą badawczą. Punktem wyjścia do rozważań powinien być skład chemiczny szkła (patrz przede wszystkim: Dekówna, 1980, s. 21 i n.; Stawiarska, 1984, 1987; Ščapova, 1973). Ponieważ metodami laboratoryjnymi przebadano jedynie 8 przedmiotów, jako podstawę klasyfikacji przyjęto technikę wykonania i zdobienia, a wyniki badań fizyko-chemicznych i ich interpretację podano przy opisie przebadanych okazów ${ }^{2}$. Trzeba nadmienić, że ograniczyło to rozważania technologiczne. Podstawą klasyfikacji typologicznych oraz formy ich zapisu były ustalenia autorów Principes... (2002).

Interpretację wyników fizyko-chemicznych analiz składu szkła oraz ich klasyfikację oparto na pracach polskich badaczy, którzy przyjęli generalne kryteria określone przez Julię L. Ščapovą ${ }^{3}$. Te zasady przyjęto również w tej pracy. Przy interpretacji związków odbarwiających, zamącających i barwiących we wszystkich typach szkieł i ich koncentracji, podstawą rozważań są ustalenia autorów Principes... (2002, s. 192-198).

Laboratoryjnie przebadano 7 paciorków i fragment kółka. Pochodzą ze stanowisk: $13 \mathrm{~b}, 15 \mathrm{~d}, 15 \mathrm{c}$ oraz 77 . Zostały one zbadane metodą XRF, odmianą EDS, określaną inaczej jako analiza przy użyciu mikrosondy elektronowej lub spektrometria dyspersji energetycznej ${ }^{4}$. Kółko zostało przebadane wcześniejszą metodą jakościowej analizy spektrograficznej, a interpretację wyniku tych badań podaję za Jerzym Olczakiem (1995, s. 11, tab. 2.1).

${ }^{2}$ Katalog wyrobów w Archiwum Ośrodka Studiów Pradziejowych i Średniowiecznych Instytutu Archeologii i Etnologii PAN w Poznaniu.

${ }^{3}$ Polega na wydzieleniu poszczególnych składników szkła i określeniu ich funkcji w procesie powstawania masy szklanej. Obecność i ilość podstawowych składników szkłotwórczych $-\mathrm{SiO}_{2}, \mathrm{Na}_{2} \mathrm{O}$, $\mathrm{K}_{2} \mathrm{O}, \mathrm{CaO}, \mathrm{PbO}, \mathrm{MgO}, \mathrm{Al}_{2} \mathrm{O}_{3}$ - ma zasadniczy wpływ na jego właściwości. Obliczenie proporcji ich występowania i zestawienie w schematy wg zasad nadrzędności i podrzędności pozwala określić rodzaj, a następnie odmiany szkła. Julia L. Ščapova uściśliła i rozszerzyła wcześniejsze klasyfikacje - E. V. Sayre'go, R. W. Smitha, M. A. Bezborodova, F. R. Matsona (Ščapova, 1973 i tam dalsza lit.).

${ }^{4}$ Metoda ta ma charakter nieniszczący i mikroinwazyjny. Pozwala na oddzielenie warstwy powierzchniowej od podłoża, bada powierzchnię próbki, a nie wnętrza badanych obiektów. W przypadku zabytków szklanych o często skorodowanej powierzchni wymaga zrobienia specjalnych szlifów. Tę metodę do badań składu chemicznego szkła stosuje się w Laboratorium Bio- i Archeometrii IAE PAN. Ocena składu oparta jest na tych samych wzorcach, jakie stosowano do badań wcześniej stosowanej przez długie lata metody ilościowej analizy spektrograficznej - określa się ilościowo w procentach wagowych zawartość 17 tlenków występujących w stężeniach powyżej $0,1 \%$ (bliżej Dekówna, 2005). 


\section{PACIORKI}

Najbardziej liczną grupą w zbiorze są małe paciorki (129 okazów), o których Tadeusz Wieczorkowski w swoim krótkim opracowaniu (1939) wyrobów ze szkła i kamieni półszlachetnych z Gniezna pisał, że pochodzą przeważnie z wczesnych poziomów osadniczych (warstwy VII i VIII), obecnie datowanych na okres od ok. 940-983 do 1039 roku (najazd czeskiego księcia Brzetysława). W zdecydowanej większości są wykonane dwiema czytelnymi technikami :

- paciorki cięte z wyciąganej szklanej rurki, określone jako bisier i paciorki segmentowe (grupa 1 , typ 1 i 2 ),

- paciorki powstałe przez nawinięcie na pręt pasma szkła (grupa 2), w tym mikropaciorki (stożkowate i pierścieniowate), nazywane tak z powodu małych rozmiarów, oraz mniej liczne paciorki wykonane również tą techniką, ale o innych formach i zdobinach,

- oraz pojedyncze okazy wykonane metodą odlewania czy spiekania (grupa 3).

\section{Grupa 1. Paciorki wykonane techniką cięcia wyciąganej rurki - bisier i paciorki segmentowe}

1. Bisier to małe paciorki wykonane z cienkiej szklanej rurki powstałej przez zagięcie płytki szklanej na trzpieniu i wyciągnięcie jej do określonej długości, następnie pocięcie na małe nieprzekraczające $5 \mathrm{~mm}$ odcinki - stąd nazwa tego typu paciorków bisier cięty ${ }^{5}$. Zaliczono do tej grupy 15 małych okazów o średnicy nieprzekraczającej $4 \mathrm{~mm}$ i długość $5 \mathrm{~mm}$ i wyjątkowy okaz o długości $11 \mathrm{~mm}$ i średnicy $3 \mathrm{~mm}$; niektórzy badacze zaliczają takie paciorki jeszcze do kategorii bisier (Sode, 2004, s. 99). Pochodzą ze stanowiska 13b, z zespołu datowanego na drugą poł. X w. do 1039 roku (rys. 2: 2-4, 6-7, 11-14, 16, 19, 20, 23-26, 33). Na niektórych egzemplarzach zachował się ślad ukośnego cięcia lub pierwotna krawędź rurki. Szkło wszystkich okazów jest słabo przejrzyste lub opakowe, bladożółte lub zielone.

Na niektórych terenach bisier należy do najczęściej spotykanych typów paciorków od antyku po okres wczesnego średniowiecza, od Azji Środkowej po Europę Południową. Od VIII-IX w. jest powszechny w Europie Południowej i Środkowej. Pochodzenie takich paciorków na terenach Skandynawii w okresie wikińskim Johann Callmer wiązał z bliskowschodnimi, bliżej nieokreślonymi ośrodkami produkcyjnymi (1997, s. 89). Masowy import z Bliskiego Wschodu trwał do połowy IX w. i łączono go z masowym handlem ze Wschodu i napływem arabskiego srebra. Późniejsze pa-

\footnotetext{
${ }^{5}$ Rurkę tworzono kilkoma sposobami: przez rozciągnięcie grudki szkła z pęcherzykiem gazowym w środku, przez zagięcie i sklejeni płytki na metalowym trzpieniu i rozciągnięcie jej lub nawinięcie wirowym ruchem na trzpień spływającego pasma szkła (bliżej: Olczak, Jasiewiczowa, 1963, s. 62; Dekówna, 1980, s. 181, 293; Siegmann, 2006, s. 933-936). Te techniki zazwyczaj zostawiają ślady, które umożliwiają jej odczytanie (wydłużone pęcherze gazowe, ciągi czy ślady spoin).
} 
ciorki mogły produkować już pracownie nadbałtyckie - w Starej Ładodze (od końca VIII w., a na masową skalę od X w.) oraz w pracowniach w Haithabu (od VIII/IX w. na masową skalę w X w.) - wykorzystujących importowany surowiec (Steppuhn, 1998). W Polsce bisier odkryto na niewielu stanowiskach - w Szczecinie z X w. (Dekówna, 1980), Wolinie z drugiej połowy X w. (Dekówna, 1980, Kokora, 2019a), Santoku z X w. (Sawicka, 2019, s. 247), Bodzi (Dekówna, Purowski, 2016), Janowie Pomorskim-Truso (Dekówna, 2012). Nierzadko są to pojedyncze znaleziska, częściej spotykane na cmentarzyskach. Wyczerpującą dyskusję o technologii i zasięgu bisieru, z literaturą źródłową, zamieszcza w swoich pracach Maria Dekówna (1980; Dekówna, Purowski, 2012, s. 105-110).

Egzemplarze dłuższe, podobne wspomnianemu wyżej gnieźnieńskiemu, znane z osad i cmentarzysk wschodniej Rosji, nazywane są tam paciorkami z wyciąganej rurki i łączone z X-wiecznymi warsztatami bizantyńskimi i islamskimi (Zakharov, Kuzina, 2008, s. 174, rys. 164: 4). Trafiały tam jako lokalny towar wymienny w dalekosiężnym handlu wymiennym (paciorek - futra - srebro). Podobne egzemplarze odkryto w Haithabu (Steppuhn, 1998, tabl. 5: 17, 21, 22). Z warsztatami islamskimi łączy się egzemplarze znajdowane na terenach arabskich, np. paciorek taki z marokańskiej Basry został wykonany z rzadko tam występującego szkła typu $\mathrm{PbO}-\mathrm{Na}_{2} \mathrm{O}-$ $-\mathrm{SiO}_{2}$ - ołowiowo-sodowo-krzemowego (Robertshaw i in., 2010).

Laboratoryjnie przebadano dwa egzemplarze bisieru z Gniezna, oba paciorki pochodzą ze stan 13b:

- zachowany w całości długi, zniekształcony paciorek, o średnicy $3 \mathrm{~mm}$, długości $11 \mathrm{~mm}$. Na korpusie widoczne są podłużne smugi, ślady po rozciąganiu rurki szklanej i ukośnie cięty jeden z brzegów (ryc. 2: 33, tab. 1). Wykonany został z zielonego, słabo przejrzystego szkła sodowego, tzw. popiołowego odmiany $\mathrm{Na}_{2} \mathrm{O}-\mathrm{K}_{2} \mathrm{O}-\mathrm{CaO}-\mathrm{MgO}-\mathrm{Al}_{2} \mathrm{O}_{3}-\mathrm{SiO}_{2}$ (sodowo-potasowo-wapniowo-magnezowo-glinowo-krzemowe). Widoczne są układające się wzdłuż pionowej osi paciorka, naprzemiennie, mikropasma szkła jaśniejszego, to szkło odmiany Na2O- K2O-CaO-A12O3-SiO2 (szkło sodowo-potasowo-wapniowo-glinowo-krzemowe). Obie odmiany szkła zostały wytopione przy użyciu popiołów roślin bogatych w sód (typ szkła sodowego, popiołowego). Wprowadziły one do składu szkła tlenki alkaliczne $\mathrm{Na} 2 \mathrm{O}$ i $\mathrm{K} 2 \mathrm{O}$, tlenki $\mathrm{CaO}+\mathrm{MgO}$ pochodzą od wprowadzonego intencjonalnie surowca wapniowo-magnezowego $\mathrm{w}$ postaci przede wszystkim różnego rodzaju wapieni, związki glinu Al2O3 , poprawiające jakość masy szklanej, mogły być wprowadzone do zestawu szklarskiego jako domieszka piasku lub niekiedy nieintencjonalnie z glinianego tygla, $\mathrm{SiO} 2$ - krzemionka, to składnik piasku, podstawowego składnika każdego szkła. Wprowadziły one do składu szkła tlenki alkaliczne $\mathrm{Na} 2 \mathrm{O}$ i K2O, tlenki $\mathrm{CaO}$ $+\mathrm{MgO}$ pochodzą od wprowadzonego intencjonalnie surowca wapniowo-magnezowego w postaci przede wszystkim różnego rodzaju wapieni, związki glinu $\mathrm{Al} 2 \mathrm{O} 3$, poprawiające jakość masy szklanej, mogły być wprowadzone do zestawu szklarskiego jako domieszka piasku lub niekiedy nie intencjonalnie z glinianego tygla, $\mathrm{SiO} 2$ - krzemionka, to składnik piasku, podstawowego 

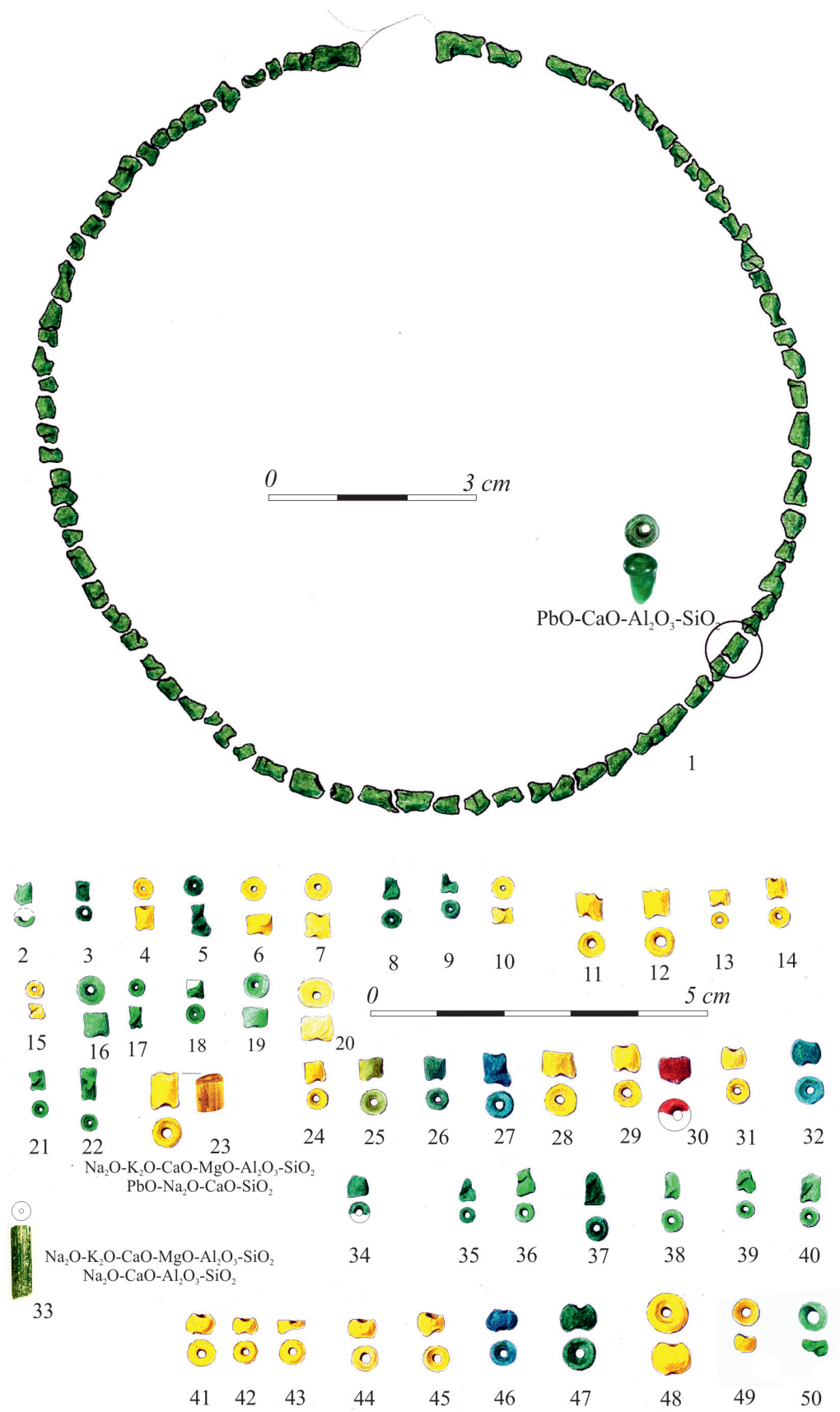

Ryc. 2. Gniezno, Góra Lecha. Paciorki szklane - bisier i mikropaciorki (ryc. i fot. J. Sawicka)

Fig. 2. Gniezno, Lech Mountain. Glass beads - fine linen and micro beads (fig. and photo by J. Sawicka) 
składnika każdego szkła. Szkło zostało zabarwione związkami miedzi i zamącone związkami ołowiu, występujących tu w małych stężeniach $(2,48 \%$ i 4,51\%) i związkami cyny. Jako środka odbarwiającego masę szklaną zastosowano znany od starożytności i stosowany w pracowniach wschodnich (arabskich) trójtlenek arsenu $\left(\mathrm{As}_{2} \mathrm{O}_{3}\right)$, który w szkle ciemniejszym wystąpił w wysokim stężeniu - 1,25\% (Dekówna, Purowski, 2016, s. 163). Duża koncentracja związków cynku $(\mathrm{ZnO})$ w obu szkłach - 1,5\% i 1,77\% wskazuje, że dodano go do masy intencjonalnie, spełniał rolę modyfikatora poprawiającego właściwości szkła i ułatwiającego proces topienia i klarowania (Kociszewski, 1966, s. 49-75, Galibin, 2001, s. 49);

- zachowany w całości mały paciorek o średnicy 3,5 mm, długości $4 \mathrm{~mm}$ i kanaliku o średnicy $1 \mathrm{~mm}$ (ryc. 2: 23, tab. 2). Wykonany z jasnożółtego opakowego szkła typu sodowego, popiołowego odmiany $\mathrm{Na}_{2} \mathrm{O}-\mathrm{K}_{2} \mathrm{O}-\mathrm{CaO}-\mathrm{MgO}-\mathrm{Al}_{2} \mathrm{O}-$ 3- $\mathrm{SiO}_{2}$ (szkło sodowo-potasowo-wapniowo-magnezowo-glinowo-krzemowe), Szkło zostało zabarwione związkami żelaza i ołowiu, jako środka mącącego użyto związków fosforu $\left(\mathrm{P}_{2} \mathrm{O}_{5}\right)$, a odbarwiającego masę szklaną związków arsenu $\left(\mathrm{As}_{2} \mathrm{O}_{3}\right)$. Podobnie jak w opisanym wyżej okazie, można zaobserwować naprzemiennie układające się mikropasma szkła różnych odcieni. Wyraźnie jaśniejsze, układające się wzdłuż pionowej osi paciorka, pasma szkła również opakowego, to szkło typu $\mathrm{PbO}-\mathrm{Na}_{2} \mathrm{O}-\mathrm{CaO}-\mathrm{SiO}_{2}$ (ołowiowo-sodowo-wapniowo-krzemowe) zabarwione głównie tlenkiem ołowiu i związkami żelaza, a zamącone związkami cyny. Według ustaleń J. L. Ščapovej, jeśli współczynnik $\mathrm{Na}_{2} \mathrm{O}+\mathrm{K}_{2} \mathrm{O} / \mathrm{CaO}+\mathrm{MgO}$ (sumy alkaliów do sumy surowca wapniowego) wynosi około 2, tak jak w przypadku okazu z Gniezna, szkło zostało wytopione w pracowniach prowincjonalno-bizantyńskich (Dekówna, Purowski, 2012, s. 101) i jako półsurowiec (raw glass) lub półfabrykat mogło trafić do przetwórczej pracowni (typu B) regionu bałtyckiego. O wschodnim pochodzeniu szkła może świadczyć obecność związków manganu $(\mathrm{MnO})$ używanych w pracowniach bizantyńskich jako odbarwiacz masy szklanej (Ščapova, 1998, s. 79).

Tabela 1. Gniezno, Góra Lecha. Wyniki analizy szkła paciorka typu bisier oraz proporcje i sumy głównych składników szkłotwórczych

Table 1. Gniezno, Lech Mountain. The results of the glass analysis of the bisier bead and the proportions and sums of the main glass-forming components

\begin{tabular}{|l|l|}
\hline Miejscowość & Gniezno, Góra Lecha, stan. 13b, III podgrodzie \\
\hline Przedmiot & Paciorek bisier \\
\hline Nr inw. & $1987: 3 / 99$ \\
\hline Chronologia zespołu & $940-983$ do 1039 r. \\
\hline Barwa i przezroczystość szkta & szkło zielone o różnych odcieniach, słabo przejrzyste \\
\hline Typ chemiczny szkta & $\begin{array}{l}\mathrm{Na}_{2} \mathrm{O}-\mathrm{K}_{2} \mathrm{O}-\mathrm{CaO}-\mathrm{MgO}-\mathrm{Al}_{2} \mathrm{O}_{3}-\mathrm{SiO}_{2}-\text { smuga ciemna } \\
\text { i Na}\end{array}$ \\
\hline
\end{tabular}




\begin{tabular}{|c|c|c|c|c|c|}
\hline \multicolumn{3}{|c|}{ Składniki (w \% wagowych) } & \multicolumn{3}{|c|}{ Proporcje i sumy głównych składników szkłotwórczych } \\
\hline & $\begin{array}{l}\text { smuga } \\
\text { ciemna }\end{array}$ & $\begin{array}{l}\text { smuga } \\
\text { jasna }\end{array}$ & & $\begin{array}{l}\text { smuga } \\
\text { ciemna }\end{array}$ & $\begin{array}{l}\text { smuga } \\
\text { jasna }\end{array}$ \\
\hline $\mathrm{SiO}_{2}$ & 56,5 & 57,43 & \multirow{2}{*}{$\mathrm{K}_{2} \mathrm{O}+\mathrm{Na}_{2} \mathrm{O}$} & \multirow{2}{*}{17,98} & \multirow{2}{*}{5,28} \\
\hline $\mathrm{Na}_{2} \mathrm{O}$ & 15,54 & 3,8 & & & \\
\hline $\mathrm{K}_{2} \mathrm{O}$ & 2,44 & 1,48 & \multirow{2}{*}{$\mathrm{Na}_{2} \mathrm{O} / \mathrm{K}_{2} \mathrm{O}$} & \multirow{2}{*}{6,36} & \multirow{2}{*}{2,56} \\
\hline $\mathrm{CaO}$ & 5,84 & 8,66 & & & \\
\hline $\mathrm{MgO}$ & 4,39 & 0,71 & \multirow{2}{*}{$\mathrm{K}_{2} \mathrm{O}+\mathrm{Na}_{2} \mathrm{O}+\mathrm{PbO}$} & \multirow{2}{*}{20,46} & \multirow{2}{*}{9,79} \\
\hline $\mathrm{Al}_{2} \mathrm{O}_{3}$ & 2,32 & 6,25 & & & \\
\hline $\mathrm{Fe}_{2} \mathrm{O}_{3}$ & 1,25 & 5,81 & \multirow{2}{*}{$\mathrm{CaO} / \mathrm{MgO}$} & \multirow{2}{*}{1,33} & \multirow{2}{*}{12,19} \\
\hline $\mathrm{MnO}$ & 0,22 & 0,2 & & & \\
\hline $\mathrm{Sb}_{2} \mathrm{O}_{5}$ & - & - & \multirow{2}{*}{$\mathrm{CaO}+\mathrm{MgO}$} & \multirow{2}{*}{10,23} & \multirow{2}{*}{9,37} \\
\hline $\mathrm{PbO}$ & 2,48 & 4,51 & & & \\
\hline $\mathrm{CoO}$ & - & - & \multirow{2}{*}{$\mathrm{K}_{2} \mathrm{O}+\mathrm{Na}_{2} \mathrm{O} / \mathrm{CaO}+\mathrm{MgO}$} & \multirow{2}{*}{1,75} & \multirow{2}{*}{0,56} \\
\hline $\mathrm{CuO}$ & 4,83 & 4,05 & & & \\
\hline $\mathrm{BaO}$ & - & - & \multirow{2}{*}{$\mathrm{K}_{2} \mathrm{O}+\mathrm{Na}_{2} \mathrm{O}+\mathrm{PbO} / \mathrm{CaO}+\mathrm{MgO}$} & \multirow{2}{*}{2,0} & \multirow{2}{*}{1,04} \\
\hline $\mathrm{TiO}_{2}$ & 0,15 & 0,27 & & & \\
\hline $\mathrm{SnO}_{2}$ & 0,03 & 0,8 & \multirow{2}{*}{$\mathrm{K}_{2} \mathrm{O}+\mathrm{Na}_{2} \mathrm{O} / \mathrm{PbO}$} & \multirow{2}{*}{7,25} & \multirow{2}{*}{1,17} \\
\hline $\mathrm{SrO}$ & - & - & & & \\
\hline $\mathrm{Cr}_{2} \mathrm{O}_{3}$ & 0,04 & 0 & \multirow{2}{*}{$\mathrm{PbO} / \mathrm{SiO}_{2}$} & \multirow{2}{*}{0,04} & \multirow{2}{*}{0,07} \\
\hline $\mathrm{NiO}$ & 0 & 0,19 & & & \\
\hline $\mathrm{ZnO}$ & 1,5 & 1,77 & \multirow{2}{*}{$\mathrm{K}_{2} \mathrm{O} / \mathrm{K}_{2} \mathrm{O}+\mathrm{Na}_{2} \mathrm{O} \times 100$} & \multirow{2}{*}{13,57} & \multirow{2}{*}{28,03} \\
\hline $\mathrm{As}_{2} 0_{3}$ & 1,25 & 0,29 & & & \\
\hline $\mathrm{Cl}$ & 0,83 & 0,58 & \multirow{3}{*}{$\mathrm{MgO} / \mathrm{CaO}+\mathrm{MgO} \times 100$} & & \\
\hline $\mathrm{P}_{2} \mathrm{O}_{5}$ & 0,36 & 2,9 & & 42,91 & 7,57 \\
\hline $\mathrm{SO}_{3}$ & 0,03 & & & & \\
\hline $\begin{array}{l}\text { Analiz: } \\
\text { orescer } \\
\text { na spek } \\
\text { Pawlic }\end{array}$ & $\begin{array}{l}\text { ana meto } \\
\text { e, metod } \\
\text { e rentgen }\end{array}$ & $\begin{array}{l}\text { ntgenow } \\
\text { S w Lab } \\
\text { kim z cyf }\end{array}$ & $\begin{array}{l}\text { ej ilościowej analizy fluoresce } \\
\text { torium Bio- i Archeometrii IAI } \\
\text { wym układem AVALON } 8000 .\end{array}$ & $\begin{array}{l}\text { ej XRF }( \\
\text { J. Badani } \\
\text { zę wykon }\end{array}$ & $\begin{array}{l}\text { Flu- } \\
\text { onano } \\
\text { żbieta }\end{array}$ \\
\hline
\end{tabular}

Tabela 2. Gniezno, Góra Lecha. Wyniki analizy szkła paciorka typu bisier oraz proporcje i sumy głównych składników szkłotwórczych

Table 2. Gniezno, Lech Mountain. The results of the glass analysis of the bisier bead and the proportions and sums of the main glass-forming components

\begin{tabular}{|l|l|}
\hline Miejscowość & Gniezno, Góra Lecha, stan. 13b, III podgrodzie \\
\hline Przedmiot & paciorek bisier \\
\hline
\end{tabular}




\begin{tabular}{|c|c|c|c|c|c|}
\hline \multicolumn{3}{|c|}{ Nr inw. } & \multicolumn{3}{|l|}{$1987: 3 / 85$} \\
\hline \multicolumn{3}{|c|}{ Chronologia zespotu } & \multicolumn{3}{|l|}{$940-983$ do 1039 r. } \\
\hline \multicolumn{3}{|c|}{ Barwa i przezroczystość szkła } & \multicolumn{3}{|c|}{ szkło opakowe i słabo przejrzyste, żółte } \\
\hline \multicolumn{3}{|c|}{ Typ chemiczny szkta } & \multicolumn{3}{|c|}{$\begin{array}{l}\mathrm{Na}_{2} \mathrm{O}-\mathrm{K}_{2} \mathrm{O}-\mathrm{CaO}-\mathrm{MgO}-\mathrm{Al}_{2} \mathrm{O}_{3}-\mathrm{SiO}_{2} \text { (szkło słabo przejrzyste) } \\
\text { i PbO- } \mathrm{Na}_{2} \mathrm{O}-\mathrm{CaO}-\mathrm{SiO}_{2} \text { (szkło opakowe) }\end{array}$} \\
\hline \multicolumn{3}{|c|}{ Składniki (w \% wagowych) } & \multicolumn{3}{|c|}{ Proporcje i sumy głównych składników szkłotwórczych } \\
\hline & $\begin{array}{c}\text { szkło } \\
\text { przejrzyste }\end{array}$ & $\begin{array}{l}\text { szkło opa- } \\
\text { kowe }\end{array}$ & & $\begin{array}{c}\text { szkło } \\
\text { opakowe }\end{array}$ & $\begin{array}{l}\text { szkło przej- } \\
\text { rzyste }\end{array}$ \\
\hline $\mathrm{SiO}_{2}$ & 62,46 & 31,62 & \multirow{2}{*}{$\mathrm{K}_{2} \mathrm{O}+\mathrm{Na}_{2} \mathrm{O}$} & \multirow{2}{*}{18,96} & \multirow{2}{*}{8,5} \\
\hline $\mathrm{Na}_{2} \mathrm{O}$ & 15,8 & 6,93 & & & \\
\hline $\mathrm{K}_{2} \mathrm{O}$ & 3,16 & 1,57 & \multirow{2}{*}{$\mathrm{Na}_{2} \mathrm{O} / \mathrm{K}_{2} \mathrm{O}$} & \multirow{2}{*}{5,00} & \multirow{2}{*}{4,41} \\
\hline $\mathrm{CaO}$ & 6,01 & 3,17 & & & \\
\hline $\mathrm{MgO}$ & 3,46 & 1,58 & \multirow{2}{*}{$\mathrm{K}_{2} \mathrm{O}+\mathrm{Na}_{2} \mathrm{O}+\mathrm{PbO}$} & \multirow{2}{*}{19,03} & \multirow{2}{*}{50,9} \\
\hline $\mathrm{Al}_{2} \mathrm{O}_{3}$ & 3,18 & 1,71 & & & \\
\hline $\mathrm{Fe}_{2} \mathrm{O}_{3}$ & 0,74 & 1,09 & \multirow{2}{*}{$\mathrm{CaO} / \mathrm{MgO}$} & \multirow{2}{*}{1,73} & \multirow{2}{*}{2,006} \\
\hline $\mathrm{MnO}$ & 2,7 & 1,35 & & & \\
\hline $\mathrm{Sb}_{2} \mathrm{O}_{5}$ & - & $<$ & \multirow{2}{*}{$\mathrm{CaO}+\mathrm{MgO}$} & \multirow{2}{*}{9,47} & \multirow{2}{*}{4,75} \\
\hline $\mathrm{PbO}$ & 0,07 & 42,4 & & & \\
\hline $\mathrm{CoO}$ & - & $<$ & \multirow{2}{*}{$\mathrm{K}_{2} \mathrm{O}+\mathrm{Na}_{2} \mathrm{O} / \mathrm{CaO}+\mathrm{MgO}$} & \multirow{2}{*}{2,002} & \multirow{2}{*}{1,78} \\
\hline $\mathrm{CuO}$ & 0,18 & 0,2 & & & \\
\hline $\mathrm{BaO}$ & - & $<$ & \multirow{2}{*}{$\mathrm{K}_{2} \mathrm{O}+\mathrm{Na}_{2} \mathrm{O}+\mathrm{PbO} / \mathrm{CaO}+\mathrm{MgO}$} & \multirow{2}{*}{2,009} & \multirow{2}{*}{10,71} \\
\hline $\mathrm{TiO}_{2}$ & 0,16 & 0,19 & & & \\
\hline $\mathrm{SnO}_{2}$ & 0 & 5,81 & 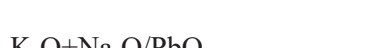 & 27095 & 020 \\
\hline $\mathrm{SrO}$ & - & $<$ & $\mathrm{K}_{2} \mathrm{U}+\mathrm{Na}_{2} \mathrm{U} / \mathrm{rDU}$ & $2 / 0,03$ & 0,20 \\
\hline $\mathrm{Cr}_{2} \mathrm{O}_{3}$ & 0,02 & 0,03 & & & \\
\hline $\mathrm{NiO}$ & 0 & 0 & $\mathrm{~K}_{2} \mathrm{O} / \mathrm{K}_{2} \mathrm{O}+\mathrm{Na}_{2} \mathrm{O} \times 100$ & 16,66 & 18,47 \\
\hline $\mathrm{ZnO}$ & 0 & 0,07 & & & \\
\hline $\mathrm{As}_{2} \mathrm{O}_{3}$ & 1,08 & 0,47 & $\mathrm{M} O \mathrm{O} / \mathrm{Co} \mathrm{O} \perp \mathrm{M} / \mathrm{O} \times 100$ & 2652 & 2226 \\
\hline $\mathrm{Cl}$ & 0,93 & 1,24 & MgUtcau+Mgo $\times 100$ & 36,53 & 35,20 \\
\hline $\mathrm{P}_{2} \mathrm{O}_{5}$ & 0,41 & 0,56 & DhO/C:O & & 124 \\
\hline $\mathrm{SO}_{3}$ & 0,36 & 0 & $\mathrm{POO} / \mathrm{SIU}{ }_{2}$ & - & 1,04 \\
\hline $\begin{array}{l}\text { Analiza } \\
\text { orescen } \\
\text { na spek } \\
\text { Pawlicl }\end{array}$ & $\begin{array}{l}\text { nana metodą } \\
R F) \text {, metodą } \mathrm{E} \\
\text { rze rentgenov }\end{array}$ & $\begin{array}{l}\text { entgenowsk } \\
\text { SS w Labora } \\
\text { kim z cyfro }\end{array}$ & $\begin{array}{l}\text { j ilościowej analizy fluorescen } \\
\text { orium Bio- i Archeometrii IAE } \\
\text { ym układem AVALON 8000. A }\end{array}$ & $\begin{array}{l}\text { ej XRF (X } \\
\text { N. Badania } \\
\text { zę wykon }\end{array}$ & $\begin{array}{l}\text { ay Flu- } \\
\text { ykonano } \\
\text { Elżbieta }\end{array}$ \\
\hline
\end{tabular}

Występowanie w paciorkach dwóch mikropasm szkła o różnej barwie prawdopodobnie było efektem zamierzonym. Znane są paciorki, często segmentowe, również wykonane techniką wyciąganej rurki, w których podłużne pasma szkła są szersze 


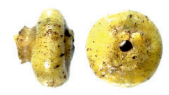

1

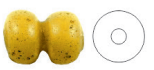

2

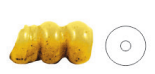

3

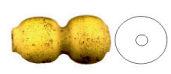

4

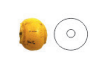

5

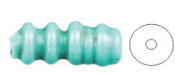

6

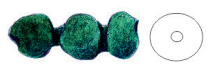

7

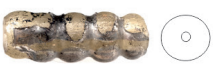

12
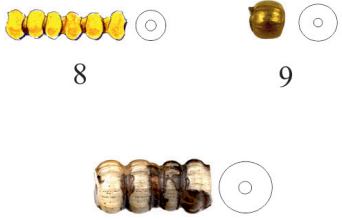

13

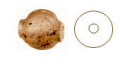

10

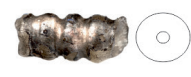

11

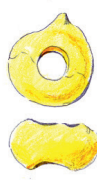

15

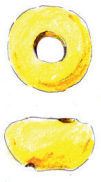

16

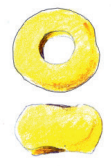

17

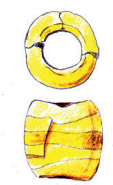

18

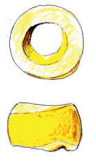

19

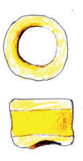

20

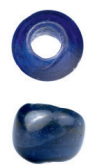

21

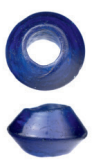

22

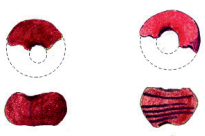

23

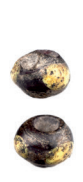

25

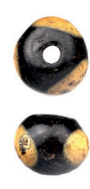

26

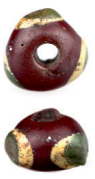

27

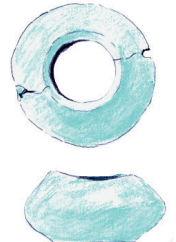

$\mathrm{Na}_{2} \mathrm{O}-\mathrm{CaO}-\mathrm{SiO}_{2}$ 31

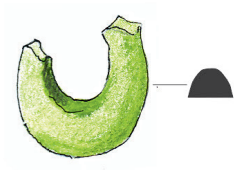

32
28

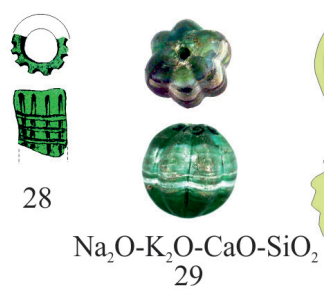

30

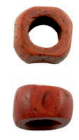

33

Ryc. 3. Gniezno, Góra Lecha. Paciorki wykonane technikami - wyciąganej rurki (paciorki segmentowe jedno- i dwuwarstwowe) oraz techniką nawijania (ryc. i fot. J. Sawicka)

Fig. 3. Gniezno, Lech Mountain. The beads are made using the techniques of pull-out tube (single and double-layer segment beads) and the winding technique (fig. and photo by J. Sawicka)

i odznaczają się jednak bardziej kontrastowymi barwami (np. Pöhe, 2005, tabl. 9; Zakharov, Kuzina, 2008, s. 178, ryc. 168; Callmer, 1977, ryc. 3). W przypadku paciorków z Gniezna (podobne odkryto w Santoku - Sawicka, 2019, s. 263, 265, tab. V.5.6-8) uzyskano efekt niejednorodnej, „,skrzącej” się powierzchni.

Paciorki typu bisier nie są wiązane z określonym typem szkła. Przebadane laboratoryjnie okazy okazy z terenów wschodniej i środkowej Europy pozwoliły określić 
je jako wykonane z dwóch różnych odmian szkła sodowego: mineralnego (soda lime glass lub soda lime silica glass) i popiołowego (soda ash glass), spotyka się również paciorki wykonane ze szkła ołowiowo-sodowo-krzemowego (Dekówna, Purowski, 2012, s. 101; Steppuhn, 1997). Biżuteria ze szkła sodowego, popiołowego odmiany $\mathrm{Na} 2 \mathrm{O}-\mathrm{K} 2 \mathrm{O}-\mathrm{CaO}-\mathrm{MgO}-\mathrm{Al} 2 \mathrm{O} 3-\mathrm{SiO} 2$, stwierdzonego w obu okazach bisieru z Gniezna, we wczesnym średniowieczu występuje powszechnie na dużym terytorium obejmującym tereny europejskie, północnej Afryki i azjatyckie (Dekówna, Purowski, 2012, s. 134). Egzemplarze bisieru z Janowa Pomorskiego (Truso) oraz okazy innych typów paciorków wykonano ze szkła tej odmiany (Dekówna, Purowski, 2012, s. 101, 131, 133, 134). Z podobnego szkła utworzone są paciorki odkrytew skarbie z Zawady Lanckorońskiej (Dekówna, 1999, s. 61) czy w pojedynczych okazach z grodu w Sąsiadce (Sutiejsk) - Wajda, 2013, s. 96. Proporcje alkaliów $\mathrm{Na}_{2} \mathrm{O} / \mathrm{K}_{2} \mathrm{O}$, surowca wapniowego $-\mathrm{CaO} / \mathrm{MgO}$ czy proporcje alkaliów do surowca wapniowego $\mathrm{Na}_{2} \mathrm{O}+\mathrm{K}_{2} \mathrm{O} /$ $\mathrm{CaO}+\mathrm{MgO}$ okazów z Gniezna i różnych paciorków odkrytych w Truso są podobne. Badacze łączą pochodzenie okazów z Truso z Haithabu lub Starą Ładogą (pracownie przetwórcze), a huty, w których wytopiono to szkło, z Bliskim Wschodem.

Nowe dane dotyczące pracowni szklarskich w Wolinie wniosły opracowania starych i ostatnich odkryć autorstwa Karoliny Kokory (2019a i 2019b). Bisier należy tam do najczęściej występujących paciorków. Analiza odkrytych również nieudanych wyrobów pozwoliła na bliższe określenie asortymentu pracowni wytwarzającej od drugiej połowy X do pierwszej połowy XI w. oprócz bisieru (barwy żółtej) paciorki segmentowe jedno- $\mathrm{i}$ dwuwarstwowe (z metalową wkładką). Wytwarzane z półsurowca paciorki segmentowe reprezentują tę samą odmianę szkła Na2O-K2O-CaO-MgO-Al2O3-SiO2 co okaz bisieru z Gniezna. Również gotowe okazy bisieru z żółtego i zielonego szkła wykazują ten sam skład chemiczny. Poddane badaniom półprodukty takich paciorków wykonano jednak w pracowni wolińskiej ze szkła innych typów - ołowiowego, alkalicznego odmiany PbO-Na2O-K2O-CaO-MgO-SiO2 oraz sodowego, popiołowego odmiany Na2O-K2O-CaO-MgO-PbO-SiO2 i Na2O-K2O-CaO-MgO-Al2O3-PbO-SiO2 (Kokora, 2019a, s. 328).

Pracownie wolińskie są współczesne poziomom osadniczym, z których pochodzą wszystkie okazy bisieru z Gniezna (druga połowa X w. do 1039 roku). Można więc przypuszczać, że paciorki z Gniezna, pochodzące z poziomów osadniczych z drugiej połowy X - pierwszej połowy XI w. mogły pochodzić z pracowni nadbałtyckich, w tym Wolina, utrzymującego kontakty z sąsiednią Wielkopolską, będącą w tym okresie w orbicie wpływów nadbałtyckiej strefy gospodarczej.

2. Paciorki segmentowe to grupa 13 egzemplarzy, w tym 8 jednowarstwowych i 5 dwuwarstwowych z metalową wkładką - trzy ze srebrną, dwie ze „złotą”. Wszystkie pochodzą ze stanowiska $13 \mathrm{~b}$, z warstw datowanych według najnowszych ustaleń na drugą połowę X w. do 1039 roku.

Paciorki jednowarstwowe wykonano ze szkła opakowego, bladożółtego i turkusowego oraz z przejrzystego zielonego (ryc. $3: 1-8$ ). Jeden z egzemplarzy został wykonany z zagiętej na trzpieniu i prawdopodobnie nierozciągniętej płytki, nierówne segmenty uformowano narzędziem (ryc. 1: 6). W przypadku paciorków, wykonanych 
z wyciągniętej rurki segmenty uformowano $\mathrm{w}$ dwóch przypadkach narzędziem - szpikulcem? (są nierówne i posklejane), a pozostałe okazy odciśnięto w formie, posługując się szczypcami? ${ }^{6}$. We wczesnym średniowieczu zasięg tych interregionalnych i ponadczasowych form pokrywa się z zasięgiem występowania bisieru.

Paciorki segmentowe dwuwarstwowe są zdobione metalową wkładką. Na korpus wykonany z opakowego białego lub bladożółtego szkła nałożono metalową folię: następniena złotą wkładkę naniesiono wierzchnią cienką warstwę białego szkła (ryc. 3: 9, 10). W jednym przypadku na srebrną folię naniesiono warstwę żółtego szkła (ryc. 3: 13) - ten zabieg dawał wrażenie użycia folii złotej, w dwóch przypadkach na folię srebrną naniesiono warstwę białego szkła (ryc. 3: 11, 12). Nie przebadano fizyko-chemicznie żadnego z tych okazów, badanie folii mogłoby ustalić rodzaj użytego kruszcu. Jest to ważne dla rozważań o pochodzeniu tego typu paciorków. W przypadku okazów ze „złotą” folią makroskopowy ogląd uszkodzonych w niektórych miejscach powłok skłania do uznania tych wkładek za złote. Nie można w sposób jednoznaczny określić sposobu nałożenia warstwy metalu, czy w postaci folii, czy mieszaniny sproszkowanego metalu z wodą. Technika wykonania wszystkich okazów jest podobna korpus powstał z wyciągniętej rurki, na którą nałożono wkładkę i wierzchnią warstwę szkła. Segmenty formowano po nałożeniu folii, która wskutek tego zabiegu została pozrywana w niektórych miejscach.

Paciorki z metalową wkładką występują w Polsce od połowy IX w. i we wcześniejszej literaturze łączy się je z warsztatami nadreńskimi (Żak, 1957). Ustalenia Jana Żaka dotyczące chronologii napływu tego typu paciorków na ziemie polskie uszczegółowiła Maria Dekówna, wskazując na dwa główne nadbałtyckie wczesnośredniowieczne szklarskie centra wytwórcze - Starą Ładogę i Haithabu, będące również wielkimi ośrodkami handlowymi (Dekówna, Purowski, 2012, s. 162, 110-124, tam szczegółowa lit. dotycząca również segmentowych paciorków jednowarstwowych). Johann Callmer (1977, s. 99) wskazuje na pracownie bizantyńskie lub byłe bizantyńskie pracownie arabskie i ciągłość produkcji od okresu rzymskiego aż do wczesnego średniowiecza. Podobnie z pracowniami zaawansowanymi technologicznie w Syrii i Egipcie łączy je Peter Steppuhn (1997, s. 205). Istnieją różnice między paciorkami ze złotą folią z okresu rzymskiego i wędrówek ludów a paciorkami z okresu wikińskiego. Te pierwsze są mniejsze i używano złotej folii, po VI w. zaczęto często używać srebrnej, a do jej pokrywania zaczęto stosować folię srebrną i pokrywać ją szklaną żółtą powłoką, co dawało w rezultacie efekt koloru złota.

Przebadane fizyko-chemicznie dwuwarstwowe paciorki z metalową wkładką $\mathrm{z}$ cmentarzyska w Bodzi, datowane na przełom IX/X w. do roku 1030, autorzy łączą zasadniczo z pracowniami bliskowschodnimi, nie wykluczając jednak produkcji w Haithabu i Starej Ładodze, z półfabrykatów sprowadzonych z pracowni bliskowschodnich (Dekówna, Purowski, 2016, s. 162). Tam też odkryto zespoły paciorków składających się jedynie z jednego segmentu, podobnie jak okaz z Gniezna (ryc. 3: 10). Również badacze rosyjscy tego typu paciorki z X-XI w. łączą z pracowniami bizantyńskimi

\footnotetext{
${ }^{6}$ Bliżej o technikach produkcji paciorków segmentowych patrz: Siegmann, 2006, s. 926-955.
} 
lub bliskowschodnimi, wskazując na późniejsze, prężnie rozwijające się po XI w. pracownie Rusi Kijowskiej, stosujące folię srebrną (Ščapova, 1998, s. 137; Kuzina, 2016, s. 219-220).

\section{Grupa 2. Paciorki wykonane techniką nawijania pasma szkła}

1. Mikropaciorki to paciorki wykonane przez nawinięcie, zazwyczaj jednokrotne, pasma szkła lepkiego na pręt (Callmer, 1977, s. 35). Różnią się od bisieru techniką wykonania, ale ich rozmiary są zbliżone. W zbiorze z Gniezna wyróżniono dwie odmiany tych paciorków - wydłużone, o przekroju stożkowatym, z dobrze widocznym stożkowatym kanalikiem i niewtopionymi pasmami szkła, oraz pierścieniowate. Wszystkie okazy takich paciorków z Gniezna wykonano ze szkła przejrzystego, zielonego i żółtego.

Najliczniej reprezentowanymi są okazy stożkowate. To duża grupa paciorków pochodząca głównie z grupowego znaleziska, kolii (?) złożonej z ok. 100 zielonych, słabo przejrzystych paciorków, ze st. 13b (Wieczorkowski, 1939, s. 117). Do czasów obecnych zachowało się ich 80 (ryc. 2: 1). Kształt paciorka został określony przez technikę wykonania - nawijanie pasma szkła, niekiedy ukośnie, na wąski pręt. Paciorki nie zostały wykonane starannie, o czym świadczy brak śladów zagładzania. Są niewielkich rozmiarów - średnica nie przekracza $5 \mathrm{~mm}$, a długość $7 \mathrm{~mm}$. Pochodzą $\mathrm{z}$ poziomu osadniczego datowanego na okres od przełomu X/XI w. do połowy XI w. Pozostałe paciorki tego typu znaleziono w nawarstwieniach z 2 połowy XII-XIII w. oraz w warstwach ogólnie datowanych na IX/X po XIII w. (ryc. 2: 5, 8, 9, 10, 15, 17, $18,21,22,28-31,34-40,48)$.

Analizie poddano jeden z paciorków z kolii (ryc. 2.1; tab. 3). Wykonano go ze szkła ołowiowego bezalkalicznego odmiany ołowiowo-wapniowo-glinowo-krzemowej ( $\left.\mathrm{PbO}-\mathrm{CaO}-\mathrm{Al}_{2} \mathrm{O}_{3}-\mathrm{SiO}_{2}\right)$. Zawartość tlenku ołowiu $(\mathrm{PbO})$ wynosi 49,56\%, tlenku wapnia pełniącego rolę stabilizatora masy szklanej $(\mathrm{CaO}) 4,79 \%$, tlenku glinu $\left(\mathrm{Al}_{2} \mathrm{O}_{3}\right)$ poprawiającego jej jakość 3,38\%. Tlenek wapnia wprowadzany intencjonalnie do masy szklanej celem poprawienia jej jakości zmniejsza skłonność szkła do rozpuszczania w wodzie, a w szkłach ołowiowo-krzemowych obniża zużycie tlenku ołowiu (Ščapova, 1973, s. 35). Dodawano go do zestawu szklarskiego w postaci naturalnie spotykanych węglanów - dolomitu czy wapieni (Kociszewski, 1966, s. 54). Barwnikiem zielonego, słabo przejrzystego szkła były związki miedzi (koncentracja $0,4 \%$ ), a duże stężenie związków fosforu $\left(\mathrm{P}_{2} \mathrm{O}_{3}\right)-6,51 \%$ może świadczyć o wprowadzeniu w postaci kostnej mączki, składnika zamącającego. Szkło tego typu wystąpiło w tyglach z ceramiki naczyniowej odkrytych w reliktach pracowni złotniczej w Poznaniu-Ostrowie Tumskim, datowanej również na schyłek X w. i pierwszą ćwierć XI w. ${ }^{7}$

\footnotetext{
${ }^{7}$ Materiały niepublikowane.
} 
Tabela 3. Gniezno, Góra Lecha. Wyniki analizy szkła paciorka stożkowatego oraz proporcje i sumy głównych składników szkłotwórczych

Table 3. Gniezno, Lech Mountain. Results of the glass cone-shaped bead analysis and the proportions and sums of the main glass-forming components

\begin{tabular}{|c|c|c|c|}
\hline \multicolumn{2}{|c|}{ Miejscowość } & \multicolumn{2}{|c|}{ Gniezno, Góra Lecha, stan. 13b, III podgrodzie } \\
\hline \multicolumn{2}{|c|}{ Przedmiot } & \multicolumn{2}{|c|}{ paciorek nieregularny, stożkowaty, z kolii } \\
\hline \multicolumn{2}{|c|}{ Nr inw. } & \multicolumn{2}{|c|}{$1988: 10$} \\
\hline \multicolumn{2}{|c|}{ Chronologia zespolu } & \multicolumn{2}{|l|}{ 983-1038 r. } \\
\hline \multicolumn{2}{|c|}{ Barwa i przezroczystość szkła } & \multicolumn{2}{|c|}{ szkło zielone, słabo przejrzyste } \\
\hline \multicolumn{2}{|c|}{ Typ chemiczny szkła } & \multicolumn{2}{|c|}{$\mathrm{PbO}-\mathrm{CaO}-\mathrm{Al}_{2} \mathrm{O}_{3}-\mathrm{SiO}_{2}$} \\
\hline \multicolumn{2}{|c|}{$\begin{array}{c}\text { Składniki } \\
\text { (w \% wagowych) }\end{array}$} & \multicolumn{2}{|c|}{$\begin{array}{c}\text { Proporcje i sumy głównych składników } \\
\text { szkłotwórczych }\end{array}$} \\
\hline $\mathrm{SiO}_{2}$ & 34,1 & \multirow{2}{*}{$\mathrm{K}_{2} \mathrm{O}+\mathrm{Na}_{2} \mathrm{O}$} & \multirow{2}{*}{0} \\
\hline $\mathrm{Na}_{2} \mathrm{O}$ & 0 & & \\
\hline $\mathrm{K}_{2} \mathrm{O}$ & 0 & \multirow{2}{*}{$\mathrm{Na}_{2} \mathrm{O} / \mathrm{K}_{2} \mathrm{O}$} & \multirow{2}{*}{0} \\
\hline $\mathrm{CaO}$ & 4,79 & & \\
\hline $\mathrm{MgO}$ & 0 & \multirow{2}{*}{$\mathrm{K}_{2} \mathrm{O}+\mathrm{Na}_{2} \mathrm{O}+\mathrm{PbO}$} & \multirow{2}{*}{49,56} \\
\hline $\mathrm{Al}_{2} \mathrm{O}_{3}$ & 3,38 & & \\
\hline $\mathrm{Fe}_{2} \mathrm{O}_{3}$ & 1,07 & \multirow{2}{*}{$\mathrm{CaO} / \mathrm{MgO}$} & \multirow{2}{*}{0} \\
\hline $\mathrm{MnO}$ & 0,06 & & \\
\hline $\mathrm{Sb}_{2} \mathrm{O}_{5}$ & - & \multirow{2}{*}{$\mathrm{CaO}+\mathrm{MgO}$} & \multirow{2}{*}{4,79} \\
\hline $\mathrm{PbO}$ & 49,56 & & \\
\hline $\mathrm{CoO}$ & - & \multirow{2}{*}{$\mathrm{K}_{2} \mathrm{O}+\mathrm{Na}_{2} \mathrm{O} / \mathrm{CaO}+\mathrm{MgO}$} & \multirow{2}{*}{0} \\
\hline $\mathrm{CuO}$ & 0,4 & & \\
\hline \multicolumn{2}{|l|}{$\mathrm{BaO}$} & \multirow{2}{*}{$\begin{array}{l}\mathrm{K}_{2} \mathrm{O}+\mathrm{Na}_{2} \mathrm{O}+\mathrm{PbO} / \mathrm{Ca}- \\
\mathrm{O}+\mathrm{MgO}\end{array}$} & \multirow{2}{*}{10,34} \\
\hline $\mathrm{TiO}_{2}$ & 0 & & \\
\hline $\mathrm{SnO}_{2}$ & - & \multirow{2}{*}{$\mathrm{K}_{2} \mathrm{O}+\mathrm{Na}_{2} \mathrm{O} / \mathrm{PbO}$} & \multirow{2}{*}{0} \\
\hline $\mathrm{SrO}$ & & & \\
\hline $\mathrm{Cr}_{2} \mathrm{O}_{3}$ & - & \multirow{2}{*}{$\mathrm{PbO} / \mathrm{SiO}_{2}$} & 145 \\
\hline $\mathrm{NiO}$ & - & & 1,45 \\
\hline $\mathrm{ZnO}$ & 0 & & \\
\hline $\mathrm{As}_{2} \mathrm{O}_{3}$ & - & $\mathrm{K}_{2} \mathrm{O} / \mathrm{K}_{2} \mathrm{O}+\mathrm{Na}_{2} \mathrm{O} \times 100$ & 0 \\
\hline $\mathrm{Cl}$ & - & & \\
\hline $\mathrm{P}_{2} \mathrm{O}_{3}$ & 6,51 & $\mathrm{MgO} / \mathrm{CaO}+\mathrm{MgO} \times 100$ & 0 \\
\hline $\mathrm{SO}_{3}$ & - & & \\
\hline $\begin{array}{l}\text { Analiz } \\
\text { scence } \\
\text { tometr }\end{array}$ & nowski & $\begin{array}{l}\text { wej analizy fluorescencyj } \\
\text { rcheometrii IAE PAN. Ba } \\
\text { LON 8000. Analizę wyk }\end{array}$ & $\begin{array}{l}\text { X-Ray Fluor } \\
\text { tonano na spe } \\
\text { ieta Pawlicka }\end{array}$ \\
\hline
\end{tabular}


Duży zbiór tego typu paciorków barwy żółtej i turkusowej znaleziono w Kruszwicy w późniejszych XII-XIII-wiecznych poziomach osadniczych (przebadane laboratoryjnie okazy wykonano również ze szkła ołowiowego, bezalkalicznego $\mathrm{PbO}$ $\left.-\mathrm{SiO}_{2}\right)^{8}$ i w ośrodkach grodowych na Śląsku, w Niemczy, Opolu-Ostrówku czy Wrocławiu-Ostrowie Tumskim. Zostały wyprodukowane ze szkła ołowiowo-krzemowego zarówno bez-, jak i alkalicznego (Pankiewicz, Siemianowska, Sadowski, 2017, tab. 2, s. 58, 259, 307, 311). Pojedyncze okazy pochodzą z wschodniej Sąsiadki-Sutiejsku (Wajda, 2013, s. 100, tab. 51).W Santoku niemal analogiczne paciorki pojawiają się w poziomach osadniczych od drugiej połowy X w. (Sawicka, 2019, s. 271, ryc. 1: 24).

Paciorki pierścieniowate formowano przez zawinięcie pojedynczego pasma szkła. Okazy z Gniezna (13 egz.) są niewielkie, o średnicy nieprzekraczającej $4 \mathrm{~mm}$, płaskie, o wysokości 2-3 mm, wykonane ze szkła słabo przejrzystego, żółtego i zielonego (ryc. 2: 11, 31, 32, 41-47, 49, 50). Pochodzą ze stanowiska 13b, z poziomów osadniczych datowanych obecnie na przełom X/XI w. do połowy XI w. Podobnie jak opisane wyżej małe paciorki stożkowate oraz bisier wystąpiły w dużych ilościach m.in. w Gdańsku od początku trwania osady, tzn. od wieku X i stanowią tam duży procent ogółu paciorków (Chmielowska, 1960, s. 153). W Santoku pojedyncze okazy pojawiają się w poziomach osadniczych od czwartej ćw. IX w. (Sawicka, 2019, s. 271, ryc. 2: 8, 10, 23, 25). Znajdowane powszechnie na terenie Rusi (X-XIII w.), Niemiec, Czech, Skandynawii i Europy Zachodniej (Olczak, Jasiewiczowa, 1963, s. 54; Kuzina, 2016, rys. 2). Przyjmuje się, że mikropaciorki obu typów, podobnie jak bisier, mogły służyć nie tylko jako elementy naszyjników, ale również do obszywania nakryć głowy czy ubrań, co dokumentują znaleziska z cmentarzysk w Czersku, Kaliszu-Zawodziu (za: Jaskanis 2009, s. 98) czy Dziekanowicach (Wrzesińscy, 1995, s. 210-213).

Oprócz wspomnianych wyżej mikropaciorków wyróżniono kilkanaście większych okazów wykonanych techniką nawijania. Polega ona na nawinięciu lub zawinięciu na trzpień, odpowiadający niekiedy średnicy kanalika przyszłego paciorka, pasma szkła - pojedynczego lub wielokrotnego, o różnej grubości. Jest to najczęściej spotykana technika wykonania szklanych paciorków. Analiza formy, jak i techniki wykonania niektórych często spotykanych okazów niewiele wnosi do rozważań o chronologii i pochodzeniu, jak np. trzy duże płaskokuliste paciorki o średnicy ok. $1 \mathrm{~cm}$ i wysokości ok. 0,6 cm, wykonane ze szkła bardzo złego gatunku, nieprzejrzystego, matowego i porowatego, bladożółtego. Na korpusach widoczne są ślady niewtopionych pasm (ryc. 3: 18-20) czy dwa okazy wykonane ze szkła opakowego, wątrobiastego, o zbliżonych rozmiarach (średnica ok 4-5 mm), jeden z nich jest zdobiony wtopioną płasko dookolną cienką $(0,5 \mathrm{~mm})$ nitką z czarnego opakowego szkła (ryc. 3: 23, 24). Wyjątkiem są niektóre charakterystyczne formy:

2. Paciorek spiralny - wykonany przez koncentryczne nawinięcie wąskiego pasma szkła na trzpień. Paciorki takie przypominają okazy pierścieniowate odcinkowe. Nie są często spotykane. Okaz z Gniezna, wykonany ze słabo przejrzystego zielonego szkła, ma dwa zawinięcia takiej spirali, zapewne miał ich więcej (ryc. 3: 14).

\footnotetext{
${ }^{8}$ Materiały niepublikowane.
} 
Pochodzi ze stan.13b, z poziomu osadniczego z przełomu X/XI - pierwszej poł. XI w. Paciorki takie produkowano ze szkła różnej barwy. W Groß Menkendorf, faktorii handlowej i centrum wytwórczym, odkryto takie paciorki (Schraubenförmig) barwy czarnej i fioletowej. Pojawiają się w Nadrenii od VIII w. (Pöhe, 2005, s. 64, tab. 8: 23) i później na stanowiskach wielkomorawskich, gdzie zalicza się je do form często spotykanych (Drahotová, 2005, tab. 1/6). W Polsce analogiczne, posiadające jednak więcej zwojów, odkryto na wczesnośredniowiecznym cmentarzysku w Gdańsku (Krukowska, 2015, tabl. IA), w Święcku (Jaskanis, 2009, ryc. 49, s. 181), na cmentarzysku w Czersku (Bronicka-Rauhut, 1998, s. 27), Grucznie (Markiewicz, 2008, s. 77, ryc. 29) czy Opolu Ostrówku i Wrocławiu (Pankiewicz, Siemianowska, Sadowski, 2017, s. 55).

3. Dwa paciorki - płaskokulisty $i$ dwustożkowy z ciemnoszafirowego, prawdopodobnie barwionego związkami kobaltu szkła (ryc. 3: 21, 22), pochodzące z poziomów osadniczych datowanych obecnie na poł. X - początek XII w. W basenie Morza Bałtyckiego proste niebieskie paciorki wykonane techniką nawijania należą do przewodnich typów i tam też powstawały w niektórych warsztatach przetwórczych. Około VIII w. w Skandynawii są tak popularne, że J. Callmer nazwał to zjawisko „niebieskim okresem” (1997, s. 198). Powstawały w pracowniach przetwórczych, dokąd surowe szkło sprowadzano z zachodniej Europy kontynentalnej lub za jej pośrednictwem. Forma ta w niezmiennej postaci przeżywa się jeszcze w XI w. Wcześniejsze okazy, również wyprodukowane w pracowniach europejskich (Groß Strömkendorf, Rostock-Dierkow) czy w skandynawskim Åhus, Paviken na Gotlandii czy w Helko w rejonie jeziora Malar w Szwecji zasadniczo nie różnią się formą od późniejszych egzemplarzy z Yorku czy Haithabu (Pöhe, 2005, s. 47-48). Badacze rosyjscy odkrywane we wschodniej Europie okazy dwustożkowate łączą z pracowniami bizantyńskimi (Ščapova, 1998, s. 140; Kuzina, 2016, s. 222).

4. Ringperlen? kótko? zawieszka? - nieregularny okaz znacznie odbiegający wymiarami od opisanych powyżej, jest duży, elipsoidalny, o średnicy $16 \mathrm{~mm}$, i większym otworze. Utworzony z jasnozielonego przejrzystego szkła. Wykonany został techniką nawinięcia pojedynczego pasma szkła, pałeczki?, szkła na gładkim i twardym podłożu, którego odcisk jest doskonale widoczny. Znaleziony został na st. 14 (katedra) w warstwach rumoszowych. Mógł być używany jako zawieszka (ryc. 3: 32).

5. Zawieszka?, przęślik? - pochodzi ze stanowiska 13b z poziomu osadniczego datowanego na drugą połowę X w. do 1039 roku; jest to duży, zachowany w całości dwustożkowy, lekko spłaszczony paciorek o średnicy $2 \mathrm{~cm}$ i średnicy prostego kanalika $0,8 \mathrm{~cm}$, wykonany z białoniebieskiego, przezroczystego szkła (ryc. 3: 31). Paciorek jest duży, mógł być ozdobną zawieszką lub małym przęślikiem. Liczne małe pęcherze gazowe i smugi układają się wzdłuż nawiniętego pasma szkła. Paciorek wykonano ze szkła sodowego typu $\mathrm{Na}_{2} \mathrm{O}-\mathrm{CaO}-\mathrm{SiO}_{2}$ (sodowo-wapniowo-krzemowego) wytopionego na bazie sody pochodzenia mineralnego (soda lime glass) i barwionego związkami miedzi (tab. 4). Jest to stara receptura (tzw. recepta antyczna, klasyczna), według której wytapiano szkło od XVI stulecia p.n.e aż do VIII/IX w. n.e. na wielkim obszarze. Receptura ta ewoluowała, ponieważ wprowadzano innowacje technologicz- 
ne i stosowano różne surowce. Po X w. wykorzystywanajest jeszcze przez niektóre europejskie warsztaty, w tym kijowskie (Dekówna, 1980, s. 11). Według J. L. Ščapovej proporcje składników alkalicznych $\left(\mathrm{K}_{2} \mathrm{O} / \mathrm{K}_{2} \mathrm{O}+\mathrm{Na}_{2} \mathrm{O}\right.$ x 100) oraz sumy alkaliów do sumy surowców wapniowych $\left(\mathrm{K}_{2} \mathrm{O}+\mathrm{Na}_{2} \mathrm{O} / \mathrm{CaO}+\mathrm{MgO}\right)$ okazu gnieźnieńskiego wpisują się w wyznaczniki szkieł bizantyńskich (1998, s. 145, tab. 19). Również samą formę tych dużych przezroczystych okazów autorka łączy z pracowniami bizantyńskimi, choć występują one na Rusi w nieco innych barwach (1998, s. 136-137). Podobny przęślik? pochodzący z XI-XIII w., będący bizantyjskim importem, znaleziono w Sypniewie k/Kalisza (Dekówna, 1970, s. 24-25). Zbliżone wielkością okazy z białego szkła znane są z cmentarzyska z X-XII w. w Halimba-Cseres na Węgrzech (Szilágy, 1994, s. 88, 91).

6. Paciorek o przekroju poprzecznym kwadratowym, ze ściętymi narożnikami, bez dokładnego datowania, pochodzi ze stan. $13 \mathrm{~b}$ (połowa X - początek XII w.). Wykonany został z brunatno-czerwonego, opakowego szkła. Jego szerokość to $5 \mathrm{~mm}$, a wysokość $4 \mathrm{~mm}$ (ryc. 3: 33). Został przycięty z rurki wykonanej przez wielokrotne nawinięcie cienkiego pasma szkła na szeroki trzpień, co jest widoczne na zagładzonych powierzchniach przy kanalikach, a następnie uformowany płaskim narzędziem. Paciorki takie znane są z Haithabu (Steppuhn 1998, tabl. 4: 63).

7. Paciorki dwuwarstwowe z metalowa ,zlota" folia - odkryto trzy paciorkibeczułkowaty i dwa cylindryczne, na stanowisku 13b, z poziomów osadniczych obecnie datowanych na trzecią ćw. X - pierwszą poł. XI w. (ryc. 3: 18-20). Jeden z egzemplarzy wymieniony w pracy T. Wieczorkowskiego (1939, s. 119, tab. LIX: 16) pochodzi z poziomu osadniczego obecnie datowanego na drugą poł. X w. Dwa egzemplarze są zdobione grubym pasmem złotej folii, pokrytej bladożółtym szkłem, na jednym z egzemplarzy złota wkładka jest niewielka, szerokości ok. $2 \mathrm{~mm}$, a pasmo szkła pokrywające ją jest węższe od korpusu paciorka. Złota blaszka i pokrywająca ją cienka płytka bladożółtego szkła zostały nałożone na korpus paciorka razem, przedtem prawdopodobnie stopiono je ze sobą. Widoczna jest wyraźnie „zakładka" na korpusie paciorka (ryc. 3: 18). Te zaobserwowane szczegóły techniczne mogą wnieść nowe wskazówkido rekonstrukcji aplikowania folii na korpusy takich paciorków. Daleko posunięta korozja nie pozwoliła określić stopnia przejrzystości korpusów. Paciorki o przekroju beczułkowatym i cylindrycznym, zdobione złotą folią, stanowią dość liczne znaleziska ze stanowisk wczesnośredniowiecznych w Gdańsku znaleziono ich 5 (Chmielowska, 1960, s. 134), z XI/XII w. i XII/XIII w., w Kruszwicy 3 egzemplarze - z pierwszej poł. XI w., końca XI w. oraz z pierwszej połowy XIII w., z Wolina 3 egz. z drugiej połowy X w., 5 na cmentarzyskach w Czersku z XII/XIII w. i Bodzi z XI w. (Dekówna, Purowski 2016). Brak analiz szkła i wkładek, egzemplarzy z Gniezna, nie pozwala na szczegółowe rozważania, ale ten typ paciorków badacze wiążą z warsztatami bliskowschodnimi - bizantyńskimi lub islamskimi. W nowszej literaturze łączy się takie paciorki również z pracowniami nadbałtyckimi (Callmer, 1997, tab. 18), co potwierdzają najnowsze ustalenia K. Kokory dotyczące Wolina. Nie ulega wątpliwości, że pochodzą z warsztatów o wysokich umiejętnościach rzemieślników. 
8. Paciorek oliwkowaty (olive-shaped beads, elipsoidalny) $\mathrm{z}$ metalową tuleją wokół kanalika. Ma wydłużony kształt, maksymalna jego średnica wynosi $7 \mathrm{~mm}$, długość $16 \mathrm{~mm}$ (ryc. 4: 5). Tuleja (o grubości 0,2 mm) prawdopodobnie wykonana ze stopu miedzi i ołowiu została zawinięta ,na zakładkę”. Pasmo białego, przezroczystego szkła nawinięto na nią dookolnie; na korpusie widoczne są ślady narzędzia, być może szczypiec? Paciorek odkryto we wczesnym poziomie osadniczym - datowanym na drugą ćw. X w. - pochodzi z warstwy spod nasypu majdanu podgrodzia, czyli z okresu budowy grodu (stan 14, katedra). Paciorek jest słabo zachowany, nosi ślady działania ognia.

Paciorki oliwkowate, różnych rozmiarów i różnej barwy szkła, są charakterystyczne dla Środkowej Europy we wczesnym średniowieczu. Okazy z metalowym trzpieniem wokół kanalika są ich odmianą; formowano je metodą nawijania miękkiego pasma szkła na metalowy trzpień. Najwięcej takich okazów odkryto w Czechach i Bawarii, a kilka w środkowych Niemczech, Słowacji i Polsce. Występują w okresie od drugiej poł. IX/pierwszą ćw. X w. po wiek XI (Košta, Tomková, 2011).

Na ziemiach polskich nie są częstymi znaleziskami. Z terenu zachodniej Polski pochodzi kilkanaście takich paciorków różnych typów - z osady przedgrodowej w Gieczu (IX w.), grodu w Gostchorzu i Połupinie na Ziemi Lubuskiej (druga połowa VIII - pierwsza połowa XI w.) i dwa z wczesnych poziomów osadniczych w Kruszwicy (wcześniejszy z osady przedgrodowej z VIII/IX - poł. X w.) i z Santoka z poziomu osadniczego z 3 ćwierci IX w. Te okazy są proste, niezdobione (Sawicka, 2016, s. 117). Z Gostynia na Dolnym Śląsku uzyskano paciorki podłużnie żeberkowane, z połowy IX - poł. X wieku (Rzeźnik, 1998, s. 385-387). Na wszystkich tych stanowiskach, podobnie jak w Gnieźnie, paciorki oliwkowate pojawiają się we wczesnych, przedpiastowskich lub wczesnopiastowskich poziomach osadniczych.

Przebadane fizykochemicznie paciorki „oliwkowate”, różnych odmian z terenu Czech, reprezentują różne typy szkieł sodowych - najliczniejszy zbiór to szkła sodowe mineralne odmiany Na2O-CaO-A12O3-SiO2 (Košta, Tomková, 2011, tab. 3, s. 322). Metalowe trzpienie wykonano ze stopu miedzi i ołowiu. Egzemplarze z Gostchorza, Połupina, Giecza i Kruszwicy reprezentują również typ szkła sodowego mineralnego odmiany sodowo-wapniowo-glinowo-krzemowej, Na2O-CaO-Al2O3-SiO2. Przebadane tuleje to stopy o różnej koncentracji związków ołowiu i miedzi oraz wyjątkowo (jeden z egzemplarzy z Kruszwicy) - żelaza i miedzi (Sawicka 2016, s. 117). Paciorek z Santoka wykonano z innego rodzaju szkła, zaliczanego do grupy szkieł potasowych odmiany CaO-K2O-MgO-Al2O3-SiO2. Może pochodzić z pracowni, w której używano szkła sprowadzanego z huty europejskiej, stosującej znaną od VIII w. recepturę potasową. Topnikiem alkalicznym zamiast sody (mineralnej bądź uzyskanej ze spopielałych słonorośli) były popioły z roślin kontynentalnych (Sawicka, 2019, s. 27071, tab. V.5.28). Można przypuszczać, że paciorek z Gniezna wykonany został ze szkła jednej z dwóch wspomnianych wyżej grup - szkła sodowego lub potasowego. Mimo odkrycia śladów miejscowej wytwórczości szklarskiej w Czechach, Morawach i na Słowacji (pracownie w Mikulčicach z IX - pocz, X w., Nitrze z IX w., ze Starego Města z IX w., w Bratysławie-Devinskej Kobyle z IX-X w. (Olczak, 1996; Farkaš, 
Turčan, 1998) brak jest dowodów na miejscową produkcję „oliwkowatych” paciorków. Uznaje się je obecnie za import z bliżej niezlokalizowanych, ale nieodległych warsztatów przetwórczych typu B. Jako prawdopodobny dystrybutor wskazywane jest państwo wielkomorawskie (Košta, Tomková, 2011).

Tabela 4. Gniezno, Góra Lecha. Wyniki analizy szkła paciorka-zawieszki oraz proporcje i sumy głównych składników szkłotwórczych

Table 4. Gniezno, Lech Mountain. The results of the glass bead-pendant analysis, proportions and sums of the main glass-forming components

\begin{tabular}{|c|c|c|c|}
\hline \multicolumn{2}{|c|}{ Miejscowość } & \multicolumn{2}{|c|}{ Gniezno, stan. 13b, III podgrodzie } \\
\hline \multicolumn{2}{|c|}{ Przedmiot } & \multicolumn{2}{|c|}{ dwustożkowy paciorek-zawieszka } \\
\hline \multicolumn{2}{|c|}{ Nr inw. } & \multicolumn{2}{|c|}{$1957 / 18$} \\
\hline \multicolumn{2}{|c|}{ Chronologia zespołu } & \multicolumn{2}{|l|}{$940-983$ - do 1039 r. } \\
\hline \multicolumn{2}{|c|}{ Barwa i przezroczystość szkła } & \multicolumn{2}{|c|}{ szkło bladoniebieskie, przejrzyste } \\
\hline \multicolumn{2}{|c|}{ Typ chemiczny szkta } & \multirow{2}{*}{\multicolumn{2}{|c|}{$\begin{array}{l}\mathrm{Na}_{2} \mathrm{O}-\mathrm{CaO}-\mathrm{SiO}_{2} \\
\text { Proporcje i sumy głównych składników } \\
\text { szkłotwórczych }\end{array}$}} \\
\hline \multicolumn{2}{|c|}{ Składniki (w \% wagowych) } & & \\
\hline $\mathrm{SiO}_{2}$ & 70,52 & \multirow{2}{*}{$\mathrm{K}_{2} \mathrm{O}+\mathrm{Na}_{2} \mathrm{O}$} & \multirow{2}{*}{18,75} \\
\hline $\mathrm{Na}_{2} \mathrm{O}$ & 18,53 & & \\
\hline $\mathrm{K}_{2} \mathrm{O}$ & 0,22 & \multirow{2}{*}{$\mathrm{Na}_{2} \mathrm{O} / \mathrm{K}_{2} \mathrm{O}$} & \multirow{2}{*}{89,22} \\
\hline $\mathrm{CaO}$ & 7,11 & & \\
\hline $\mathrm{MgO}$ & 0,26 & \multirow{2}{*}{$\mathrm{K}_{2} \mathrm{O}+\mathrm{Na}_{2} \mathrm{O}+\mathrm{PbO}$} & \multirow{2}{*}{18,81} \\
\hline $\mathrm{Al}_{2} \mathrm{O}_{3}$ & 0,86 & & \\
\hline $\mathrm{Fe}_{2} \mathrm{O}_{3}$ & 0,36 & \multirow{2}{*}{$\mathrm{CaO} / \mathrm{MgO}$} & \multirow{2}{*}{27,34} \\
\hline $\mathrm{MnO}$ & 0 & & \\
\hline $\mathrm{Sb}_{2} \mathrm{O}_{5}$ & - & \multirow{2}{*}{$\mathrm{CaO}+\mathrm{MgO}$} & \multirow{2}{*}{7,37} \\
\hline $\mathrm{PbO}$ & 0,06 & & \\
\hline $\mathrm{CoO}$ & - & \multirow{2}{*}{$\mathrm{K}_{2} \mathrm{O}+\mathrm{Na}_{2} \mathrm{O} / \mathrm{CaO}+\mathrm{MgO}$} & \multirow{2}{*}{2,54} \\
\hline $\mathrm{CuO}$ & 0,11 & & \\
\hline $\mathrm{BaO}$ & - & \multirow{2}{*}{$\begin{array}{l}\mathrm{K}_{2} \mathrm{O}+\mathrm{Na}_{2} \mathrm{O}+\mathrm{PbO} / \mathrm{Ca}- \\
\mathrm{O}+\mathrm{MgO}\end{array}$} & \multirow{2}{*}{2,55} \\
\hline $\mathrm{TiO}_{2}$ & 0 & & \\
\hline $\mathrm{SnO}_{2}$ & 0 & \multirow{2}{*}{$\mathrm{K}_{2} \mathrm{O}+\mathrm{Na}_{2} \mathrm{O} / \mathrm{PbO}$} & \multirow{2}{*}{312,50} \\
\hline $\mathrm{SrO}$ & - & & \\
\hline $\mathrm{Cr}_{2} \mathrm{O}_{3}$ & 0,11 & \multirow{4}{*}{$\mathrm{K}_{2} \mathrm{O} / \mathrm{K}_{2} \mathrm{O}+\mathrm{Na}_{2} \mathrm{O} \times 100$} & \multirow{4}{*}{1,17} \\
\hline $\mathrm{NiO}$ & 0,06 & & \\
\hline $\mathrm{ZnO}$ & 0,06 & & \\
\hline $\mathrm{As}_{2} \mathrm{O}_{3}$ & 0 & & \\
\hline
\end{tabular}




\begin{tabular}{|l|c|c|c|}
\hline $\mathrm{Cl}$ & 1,11 & \multirow{2}{*}{$\mathrm{MgO} / \mathrm{CaO}+\mathrm{MgO} \times 100$} & 3,52 \\
\hline $\mathrm{P}_{2} \mathrm{O}_{5}$ & 0,35 & & \\
\cline { 1 - 2 } $\mathrm{SO}_{3}$ & 0,29 & \\
\cline { 1 - 2 } $\begin{array}{l}\text { Analiza wykonana metodą rentgenowskiej ilościowej analizy fluorescencyjnej XRF (X-Ray Fluore- } \\
\text { scence, XRF), metodą EDS w Laboratorium Bio- i Archeometrii IAE PAN. Badania wykonano na spek- } \\
\text { tometrze rentgenowskim z cyfrowym układem AVALON 8000. Analizę wykonała Elżbieta Pawlicka. }\end{array}$ \\
\hline
\end{tabular}

\section{Paciorki wykonane technika nawijania i zdobione ornamentem plastycznym}

Wśród nich można wyróżnić:

9. Paciorki melonowate - odkryto dwa okazy. Ze stanowiska $15 \mathrm{~d}$, z poziomu ze schyłku XII-XIII w. pochodzi duży paciorek o średnicy $10 \mathrm{~mm}$, prostym kanaliku, z sześcioma żeberkami (ryc. 3: 29). Został wykonany z zielonego nieprzejrzystego, warstwowanego szkła, szkła jasno- i ciemnozielonego. Prawdopodobnie takie szkło miało imitować półszlachetny kamień (zielony serpentynit?, malachit?). Reprezentuje szkło sodowe, popiołowe odmiany $\mathrm{Na}_{2} \mathrm{O}-\mathrm{K}_{2} \mathrm{O}-\mathrm{CaO}-\mathrm{SiO}_{2}$ (sodowo-potasowo-wapniowo-krzemowe), barwione związkami miedzi. Jako środek odbarwiający zastosowano trójtlenek arsenu $\mathrm{As}_{2} \mathrm{O}_{3}$ (tab. 5).

Tabela 5. Gniezno, Góra Lecha. Wyniki analizy szkła paciorka „melonowatego” oraz proporcje i sumy głównych składników szkłotwórczych

Table 5. Gniezno, Lech Mountain. Results of the analysis of the glass of the "melon" bead and the proportions and sums of the main glass-forming components

\begin{tabular}{|c|c|c|c|}
\hline \multicolumn{2}{|c|}{ Miejscowość } & \multicolumn{2}{|c|}{ Gniezno, Góra Lecha, stan. 15d, gród książęcy } \\
\hline \multicolumn{2}{|c|}{ Przedmiot } & \multicolumn{2}{|c|}{ paciorek „melonowaty” } \\
\hline \multicolumn{2}{|c|}{ Nr inw. } & \multicolumn{2}{|c|}{$3 / 1959$} \\
\hline \multicolumn{2}{|c|}{ Chronologia zespolu } & \multicolumn{2}{|c|}{ koniec XII-XIII w. } \\
\hline \multicolumn{2}{|c|}{ Barwa i przezroczystość szkła } & \multicolumn{2}{|c|}{ szkło zielone, słabo przejrzyste } \\
\hline \multicolumn{2}{|c|}{ Typ chemiczny szkta } & \multicolumn{2}{|c|}{$\mathrm{Na}_{2} \mathrm{O}-\mathrm{K}_{2} \mathrm{O}-\mathrm{CaO}-\mathrm{SiO}_{2}$} \\
\hline \multicolumn{2}{|c|}{ Składniki (w \% wagowych) } & \multicolumn{2}{|c|}{$\begin{array}{l}\text { Proporcje i sumy głównych składników } \\
\text { szkłotwórczych }\end{array}$} \\
\hline $\mathrm{SiO}_{2}$ & 71,64 & \multirow{2}{*}{$\mathrm{K}_{2} \mathrm{O}+\mathrm{Na}_{2} \mathrm{O}$} & \multirow{2}{*}{18,94} \\
\hline $\mathrm{Na}_{2} \mathrm{O}$ & 16,19 & & \\
\hline $\mathrm{K}_{2} \mathrm{O}$ & 2,75 & \multirow{2}{*}{$\mathrm{K}_{2} \mathrm{O} / \mathrm{Na}_{2} \mathrm{O}$} & \multirow{2}{*}{0,16} \\
\hline $\mathrm{CaO}$ & 6,04 & & \\
\hline $\mathrm{MgO}$ & 0,08 & \multirow{2}{*}{$\mathrm{K}_{2} \mathrm{O}+\mathrm{Na}_{2} \mathrm{O}+\mathrm{PbO}$} & \multirow{2}{*}{18,94} \\
\hline $\mathrm{Al}_{2} \mathrm{O}_{3}$ & 0,34 & & \\
\hline
\end{tabular}




\begin{tabular}{|c|c|c|c|}
\hline $\mathrm{Fe}_{2} \mathrm{O}_{3}$ & 0,21 & \multirow{2}{*}{$\mathrm{CaO} / \mathrm{MgO}$} & \multirow{2}{*}{75,5} \\
\hline $\mathrm{MnO}$ & 0,07 & & \\
\hline $\mathrm{Sb}_{2} \mathrm{O}_{5}$ & - & \multirow{2}{*}{$\mathrm{CaO}+\mathrm{MgO}$} & \multirow{2}{*}{6,12} \\
\hline $\mathrm{PbO}$ & 0 & & \\
\hline $\mathrm{CoO}$ & 2 & \multirow{2}{*}{$\mathrm{K}_{2} \mathrm{O}+\mathrm{Na}_{2} \mathrm{O} / \mathrm{CaO}+\mathrm{MgO}$} & \multirow{2}{*}{3,09} \\
\hline $\mathrm{CuO}$ & 0,2 & & \\
\hline $\mathrm{BaO}$ & - & \multirow{2}{*}{$\begin{array}{l}\mathrm{K}_{2} \mathrm{O}+\mathrm{Na}_{2} \mathrm{O}+\mathrm{PbO} / \mathrm{Ca}- \\
\mathrm{O}+\mathrm{MgO}\end{array}$} & \multirow{2}{*}{3,09} \\
\hline $\mathrm{TiO}_{2}$ & 0,13 & & \\
\hline $\mathrm{SnO}_{2}$ & 0 & \multirow{3}{*}{$\mathrm{K}_{2} \mathrm{O}+\mathrm{Na}_{2} \mathrm{O} / \mathrm{PbO}$} & \multirow{3}{*}{0} \\
\hline $\mathrm{SrO}$ & - & & \\
\hline $\mathrm{Cr}_{2} \mathrm{O}_{3}$ & 0,27 & & \\
\hline $\mathrm{NiO}$ & 0 & \multirow{3}{*}{$\mathrm{K}_{2} \mathrm{O} / \mathrm{K}_{2} \mathrm{O}+\mathrm{Na}_{2} \mathrm{O} \times 100$} & \multirow{3}{*}{14,51} \\
\hline $\mathrm{ZnO}$ & 0,08 & & \\
\hline $\mathrm{As}_{2} \mathrm{O}_{3}$ & 1,31 & & \\
\hline $\mathrm{Cl}$ & 0,19 & \multirow{3}{*}{$\mathrm{MgO} / \mathrm{CaO}+\mathrm{MgO} \times 100$} & \multirow{3}{*}{1,30} \\
\hline $\mathrm{P}_{2} \mathrm{O}_{5}$ & 0,28 & & \\
\hline $\mathrm{SO}_{3}$ & 0,2 & & \\
\hline \multicolumn{4}{|c|}{$\begin{array}{l}\text { Analiza wykonana metodą rentgenowskiej ilościowej analizy fluorescencyjnej XRF ( } X \text {-Ray Fluore- } \\
\text { scence, } X R F \text { ), metodą EDS w Laboratorium Bio- i Archeometrii IAE PAN. Badania wykonano na spek- } \\
\text { tometrze rentgenowskim z cyfrowym układem AVALON 8000. Analizę wykonała Elżbieta Pawlicka. }\end{array}$} \\
\hline
\end{tabular}

Podobny, choć chronologicznie wcześniejszy paciorek znaleziony na stan. 14 (katedra) w warstwie z XI w. wykonany jest ze szkła przejrzystego biało-zielonego, o średnicy $12 \mathrm{~mm}$. Oba okazy z Gniezna są kuliste, lekko spłaszczone, o starannie wymodelowanych żeberkach.

Paciorki tego rodzaju to jedne z najstarszych, interregionalnych form, znanych w Egipcie od czasów XIX dynastii (XII w. p.n.e.), w Europie od okresu lateńskiego (Dekówna, 1980, s. 59-60), powszechne w okresie rzymskim, często znajdowane są na stanowiskach z VII-VIII w., na terenach dzisiejszej Saksonii i Szwabii (Stepphun 1998, s. 32-33), a zwłaszcza na datowanych od IX w. w Skandynawii i Europie Wschodniej (Callmer, 1977, 219 i n.). Wystąpiły w Czechach na stanowiskach z okresu wielkomorawskiego (Kruphanzlova, 1965, s. 168; Hruby, 1955, tab. 89, 59), w Niemczech (Arbman, 1940, tabl. 122, 123). Pracownie w Haithabu produkowaty paciorki „melonowate” w IX i X w., głównie niebieskie i zielone, różnych kształtów i o różnej licybie żeberek (Stepphun, 1998, s. 32-33). Egzemplarz z Gniezna obok interegionalnej i starej formy ma inne cechy. Szkło imitujące kamienie szlachetne, znane już od starożytności i cenione szczególnie w okresie rzymskim, było produkowane w bliskowschodnich warsztatach. $\mathrm{Z}$ takiej produkcji słynęły pracujące jeszcze do podbojów arabskich w VII w. n.e. pracownie w Aleksandrii (Filarska, 1952, s. 23-24; Nowotny, 1958, s. 18). Można przypuszczać, że te stare tradycje konty- 


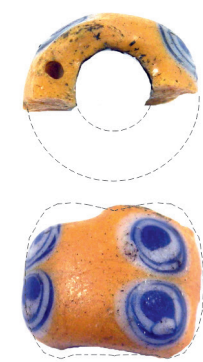

1

$\mathrm{Na}_{2} \mathrm{O}-\mathrm{PbO}-\mathrm{CaO}-\mathrm{SiO}_{2}$
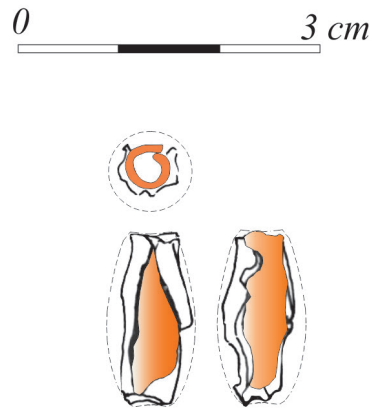

5

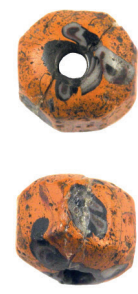

2
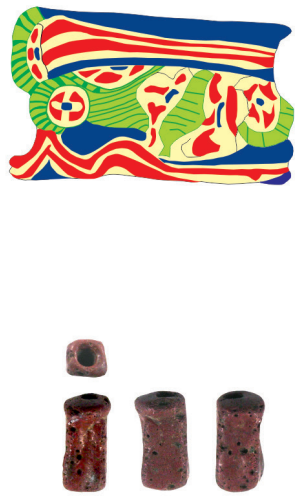

$\mathrm{PbO}-\mathrm{SiO}_{2}$

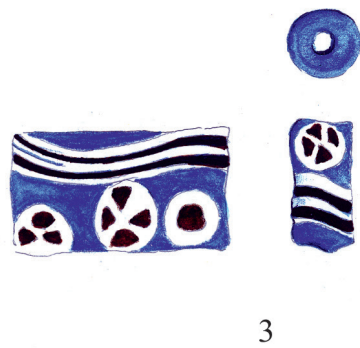

(O)
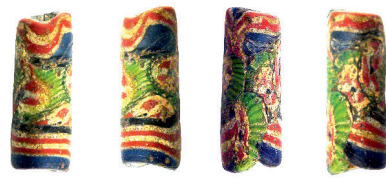

4

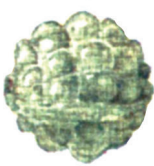

a

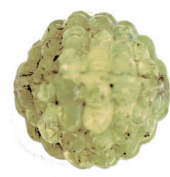

$\mathrm{b}$
6

7

Ryc. 4. Gniezno, Góra Lecha. Paciorki zdobione techniką millefiori, paciorek oliwkowaty, paciorki wykonane techniką spiekania i odlewania (ryc. i fot. J. Sawicka)

Fig. 4. Gniezno, Lech Mountain. Beads decorated with the millefiori technique, olive bead, beads made by sintering and casting (fig. and photo by J. Sawicka)

nuowano w okresie wczesnośredniowiecznym. Dwa analogiczne paciorki imitujące półszlachetne kamienie odkryto w Kruszwicy, w poziomie osadniczym z pierwszej poł. XII w.9:

10. Paciorek zdobiony „,kratką” wykonaną ostrym narzędziem (blackberry, jagodowy, kukurydziany). Uformowano go techniką zawinięcia szerokiego pasma na trzpień. Jest to paciorek cylindryczny, o średnicy $6 \mathrm{~mm}$ i wysokości $12 \mathrm{~mm}$, wykonany z nieprzezroczystego zielonego szkła (ryc. 3: 28), datowany na XII w. Paciorki takie znane są ze Szczecina (Dekówna, 1980, s. 107), Gdańska (Chmielowska, 1960, s. 133, tab. 1:14), Kruszwicy, z połowy XII w., Milicza (Sawicka, 2017; w opracowaniu), Opola-Ostrówka i Wrocławia-Ostrowa Tumskiego (Pankiewicz, Siemianowska 2018, s. 55, tab. 2). Znane są z Rusi ze stanowisk z połowy XI-XII w., gdzie w zespołach występują często

9 Jeden z tych paciorków został przebadany fizyko-chemicznie, wykonano go ze szkła ołowiowego alkalicznego odmiany ołowiowo-potasowo-krzemowej $\left(\mathrm{PbO}-\mathrm{K}_{2} \mathrm{O}-\mathrm{SiO}_{2}\right)$ o dużej koncentracji tlenku potasu 13,5\%, odbarwionego tlenkiem manganu i arsenu (szkło wytopione w warsztatach bliskowschodnich?). 
z opisanymi poniżej paciorkami „trójkątnymi” (Zakharov, Kuzina 2008, s. 195), z terenów Europy Środkowej są znane egzemplarze wcześniejsze, X-wieczne (Dekówna, 1980, s. 323), na Węgrzech należą do grupy paciorków łączonych w XI-XII w. z warsztatami bizantyńskimi i kijowskimi (Szilágyi, 1997, rys. 6: 6, s. 239, 242). Johann Callmer umiejscawia produkcję takich paciorków z warsztatami bizantyńskimi (Callmer, 1997, s. 200, ryc. 18C6), podobnie jak badacze rosyjscy pojawiające się tam u schyłku X i na początku XI w. - Kuzina, 2016, s. 222). Okazy przebadane fizyko-chemicznie wykonano ze szkła wysokoołowiowego, bezalkalicznego typu $\mathrm{PbO}-\mathrm{SiO}_{2}-$ pochodzą z Kruszwicy i Milicza (Sawicka, 2017, w opracowaniu), Szczecina (Dekówna, 1980, s. 322-323) oraz z osad regionu środkowej Wołgi (Valiulina, 2016, s. 128) leżących na wschodnim wołżańskim szlaku z Bliskiego Wschodu;

11. Paciorki płaskokuliste - wykonane techniką nawijania pasma szkła i zdobione trzema plastycznymi guzkami, o przekroju poprzecznym trójkątnym (,trójkątne”, wg badaczy rosyjskich typ izmeryjski). W Gnieźnie trzy egzemplarze takich paciorków pochodzą ze stan. 13b, bez dokładniejszego datowania. Wysokość wynosi od 3 do 5 $\mathrm{mm}$, średnica od 7 do $10 \mathrm{~mm}$, zdobione są trzema guzkami, nadającymi im trójkątny kształt. W dwóch ciemnobrunatnych egzemplarzach są to guzki żółte, w trzecim, czerwonobrunatnym - zielone z żółtą obwódką (ryc. 3: 25-27). Podobne okazy znane są z Kruszwicy z nawarstwień z pierwszej połowy XI w. oraz z pierwszej połowy XII w. oraz sporadycznie z drugiej połowy XII-XIII w. (Sawicka w opracowaniu), z Gdańska z warstw XI-wiecznych (Chmielowska, 1960, s. 137) z Czermna n/Huczwą z XII/XIII w. (Zbierski, 1959, tab. X) czy Drohiczyna (Musianowicz, 1969). Paciorki w starszej polskiej literaturze zwane ,egipskimi” mają interregionalny charakter. W Europie znajduje się je na obszarach od Renu do środkowej Wołgi oraz od dolnych odcinków Dunaju i regionu Azowskiego po Bałtyk (Valiulina, 2016, s. 128). Przed $\mathrm{X}$ w., kiedy stały się powszechne, pojawiły się już w zachodniej i środkowej Europie. Po w. XI jest ich mniej (Krumhanzlova, 1965, s. 176). Odkryto je na cmentarzyskach wielkomorawskich (Poulik, 1948, tabl. XXXIX) czy w Birce (Arbman, 1940, tabl. 121). M. Dekówna łączy je z warsztatami środkowoazjatyckimi (Dekówna, 1987, s. 22), a badacze rosyjscy takie paciorki, pojawiające się na Rusi ze schyłkiem X w., z warsztatami bizantyńskimi (Kuzina, 2016, s. 222). Przebadane fizyko-chemicznie okazy ze stanowisk wschodniej Rosji, uważa się za pochodzące $\mathrm{z}$ warsztatów bizantyńskich, późniejsze XII-wieczne z pracowni z Rusi Kijowskiej. Wykonano je ze szkła wysokoołowiowego, bezalkalicznego $\mathrm{PbO}-\mathrm{SiO} 2$, podobnie jak przebadane laboratoryjnie paciorki z Kruszwicy, Santoka (Sawicka, 2019, tab. V.5.18 i V.5.19) i Wrocławia-Ostrowa Tumskiego (Pankiewicz, Siemianowska, Sadowski, 2017, s. 193).

12. Paciorki wykonane techniką nawijania i zdobione ornamentem millefiori. Do grupy tych paciorków, inaczej nazywanych mozaikowymi ${ }^{10}$, zaliczono 4 okazy różniące się wielkością, ornamentem i techniką wykonania:

${ }^{10}$ Bliżej o technice millefiori - Siegmann, 2006, s. 948-951; Tait, 1995, s. 219-221; Krzyżanowska, Frankiewicz, 2017. 
- paciorek oczkowaty - odkryto go na stan. 77, osadzie i cmentarzysku z XIIXIII w. przy kościele św. Wawrzyńca. Jest to połowa cylindrycznego paciorka o prostym kanaliku. Korpus wykonano z żółtego opakowego szkła, ornament mozaikowy został wtopiony gładko, średnica paciorka wynosi $18 \mathrm{~mm}$, średnica kanalika $7 \mathrm{~mm}$, wysokość $14 \mathrm{~mm}$. Zachowane oczka barwy kobaltowej i białej, ułożone są parami (ryc. 4: 1). Przy jednym z kanalików zachowało się niewtopione pasmo szkła oraz ślady zagładzania krawędzi. Jest to paciorek typu Schichtaugenperlen, wg klasyfikacji Natalie Venclovej typ 533 (Venclová, 2016, ryc. 4), spotykany na terenach Europy, Bliskiego Wschodu czy północnej Afryki. Na ziemiach polskich takie okazy łączone są z kulturą łużycką i pomorską, rzadziej z kulturą kurhanów zachodniobałtyjskich, z okresem HaD-LtC1. Na zachodnie obszary Polski takie paciorki napływały z terenów Czech lub Niemiec. Okaz z Gniezna został wykonany ze szkła niskomagnezowego LMG ${ }^{11}$, barwionego związkami ołowiu, jako środka zamącającego użyto związków cyny. Skład chemiczny niemal analogicznego paciorka z Owidza, z Pomorza Gdańskiego, wykazuje duże zbieżności składu chemicznego z okazem z Gniezna (Purowski, 2019, tab. 5.27 i tab. 6 w tej pracy). Paciorek z Gniezna ma jedynie wyższą zawartość cyny i cynku. Przyjmuje się, że szkło użyte do wyrobu takich paciorków wytopiono w warsztatach Mezopotamii czy Syro-Palestyny i w postaci półfabrykatów eksportowano do warsztatów europejskich (bliżej, razem z klasyfikacją i obszerną literaturą, Purowski, 2019, s. 223-229). Brak jest dotychczas jakichkolwiek informacji o odkryciu śladów osadnictwa z okresu epoki żelaza w pobliżu kościoła św. Wawrzyńca. Trzeba przyjąć, że paciorek jest przypadkowym znaleziskiem;

- paciorek cylindryczny, o prostym kanaliku, zdobiony techniką millefiori. Ornament wtopiony jest płasko. Składa się z pięciu wąskich $(1 \mathrm{~mm})$, falistych i równoległych pasm szkła naprzemiennie białych i brunatnych na niebieskim tle. Poniżej znajdują się 3 stylizowane proste biało-brunatne rozetki o średnicy ok. $5 \mathrm{~mm}$, średnica paciorka $7 \mathrm{~mm}$, długość paciorka $14 \mathrm{~mm}$, średnica kanalika $2 \mathrm{~mm}$. Na korpusie widoczny jest ślad po zespolonej nierówno płytce. Szkło korpusu i ornamentu jest opakowe (ryc. 4: 3). Został znaleziony na stanowisku 13b. Brak jest bliższych danych pozwalających na dokładną datację. Można ją ogólnie określić na ok. połowę X - początek XII w.;

- paciorek cylindryczny, z nieregularnym, kwiatowym ornamentem, zniekształconym pod wpływem wysokiej temperatury, prawdopodobnie przy formowaniu paciorka. Na ciemnoniebieskim tle korpusu, przy krawędziach

${ }^{11}$ Dla szkieł z epoki brązu i wczesnej epoki żelaza podstawowym kryterium podziału jest stosunek tlenków potasu (K2O) do tlenków magnezu (MgO). Na tej podstawie wyróżnia się szkła wysokomagnezowe (HMG - High Magnesium Glass), niskomagnezowe LMG (Low Magnesium Glass) oraz mieszane (LMNH - Low Magnesium, High Potassium Glass). Szkła niskomagnezowe od IX lub X w. p.n.e. zastępują szkła wysokomagnezowe, przypuszcza się, że wytapiano je z sody mineralnej. Znane są z Egiptu, Mezopotamii, Grecji, w Europie od wczesnej epoki żelaza (Purowski, 2013, s. 44 i tam szczegółowa literatura). 
przyotworowych widoczne są nieregularne pasma drobnych nici, naprzemiennie czerwonych i białych -3 białe i 2 czerwone, o szerokości $0,5-1 \mathrm{~mm}$. Na środku korpusu umieszczono ornament 5 czworokątnych czerwonych rozetek na białym tle z drobnym zielonym oczkiem w środku. Rozetki są nieregularne, o średnicy ok. $3 \mathrm{~mm}$. Przy rozetkach 5 mikroskopijnych półokrągłych wkładek (zapewne imitujących liście) z drobną mozaiką wąskich, krótkich, naprzemiennych pasm szkła jasnozielonego opakowego i przejrzystego ciemnozielonego. Wysokość paciorka to $16 \mathrm{~mm}$, średnica $5 \mathrm{~mm}$, średnica kanalika 1-2 mm. Na korpusie i na niezagładzonych krawędziach przy kanaliku widoczny jest ślad nierównego zagięcia płytki szklanej, ornamentu nie dopasowano (ryc. 4: 4).

Tabela 6. Gniezno, stan. 37. Wyniki analizy szkła paciorka z ornamentem oczkowym oraz proporcje i sumy głównych składników szkłotwórczych

Table 6. Gniezno, state. 37. Results of the glass analysis of a bead with an eyelet ornament and the proportions and sums of the main glass-forming components

\begin{tabular}{|c|c|c|c|}
\hline \multicolumn{2}{|c|}{ Miejscowość } & \multicolumn{2}{|c|}{$\begin{array}{l}\text { Gniezno, Góra Lecha, stan. } 77 \text { osada i cmentarzy- } \\
\text { sko przy kościele św. Wawrzyńca }\end{array}$} \\
\hline \multicolumn{2}{|c|}{ Przedmiot } & \multicolumn{2}{|c|}{ paciorek z ornamentem oczkowym } \\
\hline \multicolumn{2}{|c|}{ Nr inw. } & \multicolumn{2}{|c|}{$13 / 55$} \\
\hline \multicolumn{2}{|c|}{ Chronologia zespolu } & \multicolumn{2}{|c|}{ XII-XIII w., na złożu wtórnym } \\
\hline \multicolumn{2}{|c|}{ Barwa i przezroczystość szkła } & \multicolumn{2}{|c|}{ szkło opakowe, żółte } \\
\hline \multicolumn{2}{|c|}{ Typ chemiczny szkta } & \multicolumn{2}{|c|}{$\begin{array}{l}\text { Szkło niskomagnezowe LMG } \\
\mathrm{Na}_{2} \mathrm{O}-\mathrm{PbO}-\mathrm{CaO}-\mathrm{SiO}_{2}\end{array}$} \\
\hline \multicolumn{2}{|c|}{ Składniki (w \% wagowych) } & \multicolumn{2}{|c|}{$\begin{array}{l}\text { Proporcje i sumy głównych składników } \\
\text { szkłotwórczych }\end{array}$} \\
\hline $\mathrm{SiO}_{2}$ & 65,71 & \multirow{2}{*}{$\mathrm{K}_{2} \mathrm{O}+\mathrm{Na}_{2} \mathrm{O}$} & \multirow{2}{*}{11,55} \\
\hline $\mathrm{Na}_{2} \mathrm{O}$ & 10,95 & & \\
\hline $\mathrm{K}_{2} \mathrm{O}$ & 0,6 & \multirow{2}{*}{$\mathrm{K}_{2} \mathrm{O} / \mathrm{Na}_{2} \mathrm{O}$} & \multirow{2}{*}{0,05} \\
\hline $\mathrm{CaO}$ & 7,99 & & \\
\hline $\mathrm{MgO}$ & 0,3 & \multirow{2}{*}{$\mathrm{K}_{2} \mathrm{O}+\mathrm{Na}_{2} \mathrm{O}+\mathrm{PbO}$} & \multirow{2}{*}{20,95} \\
\hline $\mathrm{Al}_{2} \mathrm{O}_{3}$ & 2,01 & & \\
\hline $\mathrm{Fe}_{2} \mathrm{O}_{3}$ & 0,72 & \multirow{2}{*}{$\mathrm{CaO} / \mathrm{MgO}$} & \multirow{2}{*}{26,63} \\
\hline $\mathrm{MnO}$ & 0,02 & & \\
\hline $\mathrm{Sb}_{2} \mathrm{O}_{5}$ & - & \multirow{2}{*}{$\mathrm{CaO}+\mathrm{MgO}$} & \multirow{2}{*}{8,29} \\
\hline $\mathrm{PbO}$ & 9,0 & & \\
\hline $\mathrm{CoO}$ & - & \multirow{2}{*}{$\mathrm{K}_{2} \mathrm{O}+\mathrm{Na}_{2} \mathrm{O} / \mathrm{CaO}+\mathrm{MgO}$} & \multirow{2}{*}{1,39} \\
\hline $\mathrm{CuO}$ & 0,48 & & \\
\hline $\mathrm{BaO}$ & - & \multirow{2}{*}{$\begin{array}{l}\mathrm{K}_{2} \mathrm{O}+\mathrm{Na}_{2} \mathrm{O}+\mathrm{PbO} / \mathrm{Ca}- \\
\mathrm{O}+\mathrm{MgO}\end{array}$} & \multirow{2}{*}{2,52} \\
\hline $\mathrm{TiO}_{2}$ & 0,14 & & \\
\hline
\end{tabular}




\begin{tabular}{|c|c|c|c|}
\hline $\mathrm{SnO}_{2}$ & 0,22 & \multirow{2}{*}{$\mathrm{K}_{2} \mathrm{O}+\mathrm{Na}_{2} \mathrm{O} / \mathrm{PbO}$} & \multirow{2}{*}{1,28} \\
\hline $\mathrm{SrO}$ & - & & \\
\hline $\mathrm{Cr}_{2} \mathrm{O}_{3}$ & 0,03 & \multirow{2}{*}{$\mathrm{PbO} / \mathrm{SiO}_{2}$} & \multirow{2}{*}{0,13} \\
\hline $\mathrm{NiO}$ & 0,18 & & \\
\hline $\mathrm{ZnO}$ & 0,38 & \multirow{2}{*}{$\mathrm{K}_{2} \mathrm{O} / \mathrm{K}_{2} \mathrm{O}+\mathrm{Na}_{2} \mathrm{O} \times 100$} & \multirow{2}{*}{5,19} \\
\hline $\mathrm{As}_{2} \mathrm{O}_{3}$ & 0,09 & & \\
\hline $\mathrm{Cl}$ & 0,92 & \multirow{3}{*}{$\mathrm{MgO} / \mathrm{CaO}+\mathrm{MgO} \times 100$} & \multirow{3}{*}{3,61} \\
\hline $\mathrm{P}_{2} \mathrm{O}_{5}$ & 0,24 & & \\
\hline $\mathrm{SO}_{3}$ & 0 & & \\
\hline \multicolumn{4}{|c|}{$\begin{array}{l}\text { Analiza wykonana metodą rentgenowskiej ilościowej analizy fluorescencyjnej XRF (X-Ray Fluore- } \\
\text { scence, } X R F \text { ), metodą EDS w Laboratorium Bio- i Archeometrii IAE PAN. Badania wykonano na spek- } \\
\text { tometrze rentgenowskim z cyfrowym układem AVALON 8000. Analizę wykonała Elżbieta Pawlicka. }\end{array}$} \\
\hline
\end{tabular}

Paciorek odkryto na stan. 22 (Jezioro Święte) w nawarstwieniach zsypiskowych z Góry Lecha, powstałych w XV w. Ma wcześniejszą metrykę. Od XIV w. warsztaty weneckie produkowały i eksportowały paciorki różnych typów, również zdobione techniką millefiori, jednak okaz z Gniezna ich nie przypomina. Paciorki, analogiczne do gnieźnieńskiego, znane są z cmentarzysk wielkomorawskich z IX/X w. Na cmentarzysku wielkomorawskim w Čakajovcach koło Nitry w kolii różnych paciorków odkryto okazy analogiczne (Kouřil, 2014, s. 363, ryc. 152) . Podobne egzemplarze znalezionona cmentarzysku w Starym Městě z IX-X w. (Hruby, 1955, tab. 86: 4). Podobny paciorek odkryto w poziomie osadniczym z pierwszej połowy X w. w Santoku (Sawicka, 2019, s. 272). Wielkomorawskie paciorki $\mathrm{z}$ ornamentem oczkowym, $\mathrm{w}$ tym również wykonane techniką millefiori, pełniły tam rolę ochronnych amuletów (Galuška, 2017, s. 102-103). Paciorki cylindryczne z rozetkami, należące do podobnych typów pod względem formy i ornamentu zaliczyć można do zbliżonego chronologicznie „horyzontu” - pojawiają się od początku IX w. Na ziemiach polskich są to znaleziska rzadkie. Paciorki tego typu, wczesnośredniowieczne, nawet o wczesnej metryce znajdowane są na terenie Europy, często w koliach na cmentarzyskach (Siegmann, 1997, tab. 4 i Koch, 1998, tab. 12). Na terenach nadbałtyckich pojawiają się od VIII w., najliczniej występują w okresie od IX do XII w. (Callmer, 1977, s. 104, tabl. 20). J. Callmer takie paciorki, reprezentujące podobną formę korpusu i zdobin (ornament kwiatowy, oczkowy, ograniczony wąskimi pasmami), łączy z przetwórczymi nadbałtyckimi pracowniami skandynawskimi (1997, tab. 16, s. 99);

- paciorek graniasty, ośmioboczny, o prostym kanaliku, ze ściętymi krawędziami przyotworowymi, dwuwarstwowy, zdobiony nieregularnymi, wtopionymipłasko niewielkimi oczkami mozaikowymi (brunatne „pawie oczka” wydłużone i ułożone wachlarzowato) z podwójną otoczką cienkich czerwonych i białych pasm. Średnica paciorka wynosi $11 \mathrm{~mm}$, wysokość $8 \mathrm{~mm}$, średnica kanalika $3 \mathrm{~mm}$. Przy jednej z krawędzi kanalika widoczne są ślady zagładzania. Zie- 
lono-szary opakowy korpus pokryty został bardzo cienką warstwą lekko porowatego, pomarańczowego szkła z wtopionymi płasko czterema oczkami. Ośmioboczny kształt nadany został prawdopodobnie w graniastej formie już po nałożeniu ornamentu, na co wskazywałoby jego zniekształcenie (ryc. 4: 2). Paciorek pochodzi ze stanowiska 13b, a jego datację można określić na ok. połowę X - początek XII w. Podobne dwa okazy, czworokątne, odkryto na nieodległym $(\mathrm{ok} .30 \mathrm{~km})$ rzędowym cmentarzysku z końca $\mathrm{X}$ - połowy XI w. w Gołuniu pod Pobiedziskami (Andrałojć, 2015, ryc. 16, s. 94) oraz wielokątny paciorek na cmentarzysku w Kałdusie (Markiewicz, 2008, s. 185, ryc. 88: 4, tab. 20: 4). Analogiczne paciorki odkryto w Haithabu, a ślady produkcji stwierdzono w wikińskim Ribe (typ Augenmustern, M. Auge, oczkowate). Datowane są na ok. 1000 rok (Stepuhn, 1988, s. 52-53, Farbtafeln. Glasperlen, 1-138: 121). Mają jednokolorowy, nieprzezroczysty zielony korpus, na którym umieszczono grupy oczek (2 lub 4), tak jak w przypadku paciorka z Gniezna. Analogiczny pojedynczy okaz takiego paciorka odkryto na cmentarzysku z połowy XI w. w Minino (rejon nadwołżański, na trasie wielkiego północnego szlaku handlowego), gdzie również był rzadkim okazem (Zakharov, Kuzina, 2008, s. 180, 196, ryc. 170: 6). Opisane wyżej trzy wczesnośredniowieczne paciorki sprawiają wrażenie wykonanych niestarannie są wynikiem słabego przetwarzania wysokiej jakości półproduktów (pałeczek millefiori). Oczka są zniekształcone, a ornament nie jest dopasowany. Mogły powstać w lokalnych europejskich warsztatach przetwórczych, nieposiadających wysokich technologicznych umiejętności, a sprowadzających pałeczki millefiori z bardziej zaawansowanych ośrodków, prawdopodobnie bliskowschodnich (Theune, 2008, s. 247; Krzyżanowska, Frankiewicz, 2017).

\section{Grupa 3. Paciorki wykonane techniką odlewania i spiekania}

Rzadko spotykany paciorek w kształcie „maliny” został wykonany z prawdopodobnie przejrzystego, biało-zielonego szkła. Jego rysunek został zamieszczony w pierwszej monografii Gniezna (Wieczorkowski, 1939, tabl. LIX), sam paciorek zaginął podczas działań wojennych. Średnica wynosiła ok. $14 \mathrm{~mm}$ (ryc. 7a). Na rysunku widoczny jest szew odlewniczy, prawdopodobnie paciorek został odlany i sklejony z dwóch części, brak jest informacji o kanaliku. Został odkryty w warstwie z połowy XI w. Jak dotąd $z$ terenów Polski znany jest jedynie pojedynczy, analogiczny okaz z Kruszwicy, z poziomu osadniczego z drugiej połowy XII w. ${ }^{12}$

${ }^{12}$ Paciorek z Kruszwicy również został sklejony z dwóch oddzielnie odlanych połówek (ryc. 4: 7b). Ma niewielkiej średnicy otwór $(2 \mathrm{~mm})$ i został przebadany fizyko-chemicznie. Wykonano go ze szkła mieszanego (mixed alkali) typu $\mathrm{K}_{2} \mathrm{O}-\mathrm{Na}_{2} \mathrm{O}-\mathrm{CaO}-\mathrm{SiO}_{2}$, przy którego produkcji do szkła potasowego (z popiołów europejskich roślin) dodano, celem poprawienia jakości, prawdopodobnie stłuczkę szkła sodowego. Koncentracje alkaliów są wysokie $\mathrm{Na}_{2} \mathrm{O}-8,62 \%, \mathrm{~K}_{2} \mathrm{O}-11,68 \%$. Masę odbarwiono, stosując związki arsenu $\mathrm{As}_{2} \mathrm{O}_{3}$ w koncentracji 0,5\%, znanego już od epoki brązu (Galibin, 2001, s. 49). Szkła takie są stosunkowo rzadko spotykane. Na ziemiach czeskich odkryto kilka egzemplarzy różnych paciorków 
Szklane paciorki zdobione granulacją są rzadkością. Okaz wykonany prawdziwą metodą granulacji, stosowaną w złotnictwie, odkryto na awarskim cmentarzysku z VIII w. w Prše w północnych Czechach (Staššikova-Štukovská, Plško, Kucera, 2007, s. 19-22). Autorzy przypuszczają, że powstał w złotniczej pracowni, gdzie wysoko wyspecjalizowani jubilerzy, stosujący technikę granulacji, próbowali użyć jej przy innym wykorzystywanym materiale - szkle. Do produkcji paciorka użyto trzech odmian szkła sodowego. W przypadku okazów z Gniezna i Kruszwicy, paciorków późniejszych, mamy do czynienia z inną techniką - odlewania, ale podobną ideą dekoracyjną. Prawdopodobnie są to naśladownictwa srebrnych i złotych, zdobionych na całej powierzchni granulacją paciorków i zawieszek-gombików malinowatych, zaliczanych do charakterystycznej wielkomorawskiej biżuterii (Veligrad type) pochodzenia bizantyńsko-orientalnego, tworzonych do XI w. już w lokalnych warsztatach (Hruby, 1955, tab. 64; Kóčka-Krenz, 1997, s. 71). Nie można wykluczać, że były ozdobą zausznic albo że oprawiano je jubilersko w metalowy „koszyczek”. Takie zawieszki ze szklanymi paciorkami (innych typów) znajdowano na cmentarzyskach z okresu wielkomorawskiego w Czechach (Kouřil, 2014, s. 235, 421; Galuška, 2017, s. 169) i może być to wskazówką do sposobu użytkowania tych rzadkich i niewątpliwie elitarnych ozdób. Szklane paciorki „malinowate” nie występują w zbiorach paciorków łączonych z warsztatami nadbałtyckimi czy Środkowej Europy. Można przypuszczać, że podobnie jak metalowe okazy były przeznaczone dla odbiorcy z terenów Słowiańszczyzny.

Paciorek wykonany techniką spiekania (?) został odkryty na stan. 13b (III podgrodzie), w poziomie osadniczym datowanym od połowy X do początków XII w. Jest to zachowany w całości paciorek czworokątny, nieregularny, o prostym kanaliku. Średnica wynosi $6 \mathrm{~mm}$, wysokość $12 \mathrm{~mm}$, średnica kanalika $3 \mathrm{~mm}$. Jedna z krawędzi, przy kanaliku, jest zniekształcona, może to ślad po kształtowaniu w formie? Cechy zewnętrzne paciorka - opakowość, brunatnoczerwona barwa, miękka struktura, masa bez połysku - skłaniają do przypuszczenia, że został on wykonany techniką spiekania. Na powierzchni zachowały się liczne otwarte pęcherze gazowe (ryc. 4: 6). Został wykonany ze szkła wysokoołowiowego, bezalkalicznego $\mathrm{PbO}-\mathrm{SiO}_{2}$, barwionego związkami żelaza $(1,71 \%)$ i miedzi $(1,50 \%)$ - tab. 7 . Wysokie koncentracje związków żelaza i miedzi mogą świadczyć o zastosowaniu jako barwnika odpowiednio przygotowanych szlak metalurgicznych, które obok barwy zamąciły szkło.

Paciorki wykonane metodą spiekania, różnych kształtów, we wczesnym średniowieczu były rozpowszechnione (Pöhe, 2005, s. 52). W Haithabu znaleziono przeszło 400 egzemplarzy takich okazów (Steppuhn, 1998, s. 29). Badacze nie są zgodni, gdzie mogły być wytwarzane - w pracowniach nadbałtyckich czy Europy kontynentalnej

z XI-XII w. wykonanych z tego typu szkła (Černá, Tomková, Hulínský, 2015, 98). W Kaupang, gdzie istniała pracownia przetwórcza, odkryto barwioną kobaltem kostkę mozaiki i ułamek naczynia o zbliżonych stężeniach alkaliów. Pochodziły z zachodniej Europy, skąd sprowadzano stłuczkę, półfabrykaty i surowe szkło na potrzeby tej pracowni (Gaut, 2011, s. 263). W Wolinie w poziomie osadniczym z XI w. odkryto główkę wielokątnej, facetowanej szpili wykonanej z czarnego szkła tego typu, o nieco innych koncentracjach alkaliów (Kokora, 2019b, s. 203). 
(Callmer, 1977, s. 95). Czworokątny paciorek, wyprodukowany z takiego samego szkła, zdobiony nieregularnym wtopionym pasmem żółtego szkła, odkryto w Poznaniu-Ostrowie Tumskim w poziomie osadniczym datowanym na drugą połowę XI w. ${ }^{13}$ Paciorek wykonany z takiego tworzywa w kształcie graniastosłupa, odkryto na cmentarzysku w Bodzi, wykonano go również ze szkła ołowiowo-krzemowego $\mathrm{PbO}-\mathrm{SiO}_{2}$ i jest równoczasowy podobnym znaleziskom z obszarów Rusi Kijowskiej (Dekówna Purowski, 2016, s. 168-169).

Tabela 7. Gniezno, Góra Lecha. Wyniki analizy szkła paciorka prostopadłościennego oraz proporcje i sumy głównych składników szkłotwórczych

Table 7. Gniezno, Lech Mountain. Results of the analysis of the glass of a rectangular bead and the proportions and sums of the main glass-forming components

\begin{tabular}{|l|l|l|}
\hline Miejscowość: & Gniezno, Góra Lecha, stan. 13b, III podgrodzie \\
\hline Przedmiot: & paciorek prostopadłościenny \\
\hline Nr inw. & $1987: 3 / 108$ \\
\hline Chronologia zespołu: & $940-983$ do 1039 r. \\
\hline Barwa i przezroczystość szkta: & szkło opakowe, czerwonobrunatne \\
\hline \multicolumn{2}{|c|}{ Typ chemiczny szkla: } & PbO-SiO ${ }_{2}$ \\
\hline \multicolumn{2}{|c|}{ Proporcje i sumy głównych składników } \\
\cline { 1 - 2 } szkłotwórczych
\end{tabular}

13 Niepublikowane materiały, znane mi z autopsji. 


\begin{tabular}{|c|c|c|c|}
\hline $\mathrm{Cr}_{2} \mathrm{O}_{3}$ & 0,04 & \multirow{7}{*}{$\begin{array}{l}\mathrm{PbO} / \\
(100 \%- \\
\mathrm{PbO})\end{array}$} & \multirow{7}{*}{1,63} \\
\hline $\mathrm{NiO}$ & 0,03 & & \\
\hline $\mathrm{ZnO}$ & 0,4 & & \\
\hline $\mathrm{As}_{2} \mathrm{O}_{3}$ & 0,07 & & \\
\hline $\mathrm{Cl}$ & 1,21 & & \\
\hline $\mathrm{P}_{2} \mathrm{O}_{5}$ & 0,37 & & \\
\hline $\mathrm{SO}_{3}$ & 0 & & \\
\hline \multicolumn{4}{|c|}{$\begin{array}{l}\text { Analiza wykonana metodą rentgenowskiej ilościowej analizy fluorescencyjnej XRF ( } X \text {-Ray Flu- } \\
\text { orescence, } X R F) \text {, metodą EDS w Laboratorium Bio- i Archeometrii IAE PAN. Badania wykonano } \\
\text { na spektometrze rentgenowskim z cyfrowym układem AVALON 8000. Analizę wykonała Elżbieta } \\
\text { Pawlicka. }\end{array}$} \\
\hline
\end{tabular}

\section{KÓŁKA}

Zastosowaną w pracy klasyfikację szklanych pierścionków przyjęto za J. Olczakiem (2000, s. 316):

- pierścionek - kółko z różnie uformowanym i zdobionym oczkiem,

- obrączka - kółko bez oczka zdobione szkłem innej barwy lub plastycznym ornamentem,

- kólko - jednobarwne, bez oczka i zdobin.

Wszystkie zachowane jedynie fragmentarycznie okazy z Gniezna można przypuszczalnie określić jako kółka. Jerzy Olczak zrekonstruował cztery sposoby formowania kółek (1968, s. 190-191). Są one czytelne w przypadku okazów zachowanych w całości.

Odkryto 6 fragmentów jednobarwnych, niezdobionych kółek, pochodzących:

- ze stanowiska 13b: z warstw datowanych od IX/X-XIII w. pochodzi ułamek $\mathrm{z}$ zielono-niebieskiego, słabo przejrzystego szkła o średnicy ok. $2,2 \mathrm{~cm}$ i grubości $3 \mathrm{~mm}$, bez ścisłego datowania (IX/X-XIII w.) (ryc. 5: 1),

- ze stanowiska 14 (katedra): z warstw rumoszowych uzyskano kolejny ułamek o średnicy ok. $2 \mathrm{~cm}$ i grubości $4 \mathrm{~mm}$ wykonany z przejrzystego zielonego szkła (ryc. 5: 4),

- ze stanowiska 15 (15d) - wydzielonego grodu książęcego: z warstw niwelacyjnych, pochodzi ułamek wykonany z jasnożółtego, przejrzystego szkła o średnicy $2 \mathrm{~cm}$ i grubości $5 \mathrm{~mm}$ (ryc. 5: 6),

- ze stanowiska 5 (wschodnia część II podgrodzia), z warstwy z drugiej ćw. XIXII w. pochodzi fragm. kółka o średnicy $2,5 \mathrm{~cm}$ i grubości $4 \mathrm{~mm}$ z przejrzystego jasnozielonego szkła (ryc. 5. 2),

- ze stanowiska 15c (I podgrodzie), z nawarstwień XII-wiecznych pochodzi okaz ośrednicy 2,8cmigrubości4mmwykonanyzprzejrzystegożółtegoszkła(ryc.5:3). 


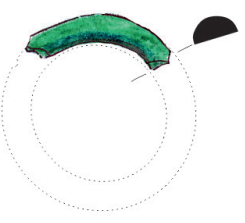

1

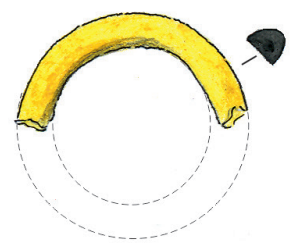

$\mathrm{PbO}-\mathrm{K}_{2} \mathrm{O}-\mathrm{SiO}_{2}$ 5

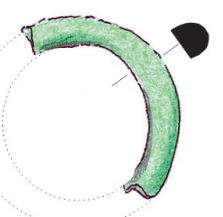

2

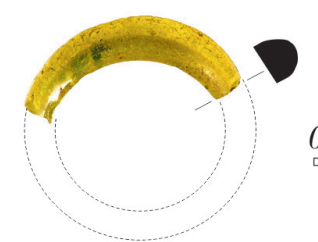

6

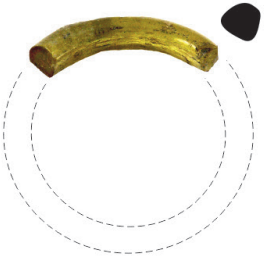

3

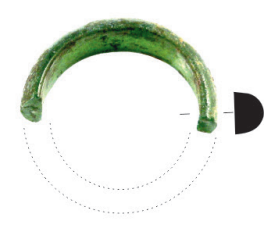

4

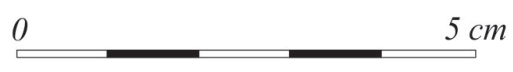

Ryc. 5. Gniezno, Góra Lecha. Szklane kółka (ryc. i fot. J. Sawicka)

Fig. 5. Gniezno, Lech Mountain. Glass wheels (fig. and photo by J. Sawicka)

Drugi, zachowany również fragmentarycznie, to połowa kółka (?) o średnicy zewnętrznej $26 \mathrm{~mm}$ i wysokości $3 \mathrm{~mm}$, o półokrągłym przekroju, z jasnożółtego przejrzystego szkła.

Jest to jedyny przebadany laboratoryjnie okaz odkryty w poziomie osadniczym z XII w. (ryc. 5: 5). Nieliczne drobne pęcherze gazowe, okrągłe i wydłużone, równoległe do osi podłużnej pałeczki i widoczne wyraźne zgrubienie na jednym z końców mogą wskazywać na formowanie przez zagięcie pałeczki szklanej lub odpad produkcyjny? (uwaga Olczaka, 1995, s. 11). Kółko wykonano ze szkła ołowiowego alkalicznego (ołowiowo-potasowo-krzemowego) $\mathrm{PbO}-\mathrm{K}_{2} \mathrm{O}-\mathrm{SiO}_{2}$, barwnikiem były związki żelaza $\left(\mathrm{Fe}_{2} \mathrm{O}_{3}\right)$ i ołowiu $(\mathrm{PbO})$. Ponieważ analiza ta została wykonana obecnie trudno porównywalną metodą analizy spektrograficznej jakościowej, nie można w sposób precyzyjny określić zawartości głównych składników szkłotwórczych. Oparto się na interpretacji J. Olczaka (Olczak, 1995, s. 11, tab. 2.1).

Pierścionki ze szkła, o różnych formach, pojawiają się na terenie wschodniej i środkowej Europy już w X w., pod koniec tego stulecia na terenach wysp brytyjskich i Skandynawii, na terenach Czech w XI w. Niekiedy przyjmuje się, że w średniowieczu zwyczaj noszenia pierścieni szklanych do Europy został przeniesiony z terenów bizantyńskich do wschodniosłowiańskiego regionu Bałkanów, skąd rozprzestrzenił się na zachód. Producentem pierścionków na obszarach zamieszkanych przez Słowian mogli być migrujący rzemieślnicy, posługujący się półfabrykatami. To thumaczy znaczną unifikację zarówno form, jak i odmian szkła, z których je produkowano, a które przez długi czas nie ewoluowały. Inicjatorami tego handlu mogli być w X w. kupcy wikińscy, rozprowadzający półfabrykaty powstałe w pierwszych pracowniach kijowskich (Urllich, 1989, s. 70). 
Pojedyncze proste kółka, zdobione obrączki i pierścionki z oczkiem odkryto już w X-wiecznych poziomach osadniczych, w większej ilości po drugiej połowie XI w. w dużych śląskich ośrodkach grodowych - Niemczy, Opolu-Ostrówku i Wrocławiu-Ostrowie Tumskim (Pankiewicz, Siemianowska, Sadowski, 2017, tab. 3, s. 59-62. Są licznymi znaleziskami tam, gdzie lokalizowano przypuszczalne szklarskie warsztaty - we Wrocławiu (Kaźmierczyk, 1970; Pankiewicz, Siemianowska, 2018), Opolu-Ostrówku, (Bukowska-Gedigowa, Gediga, 1986), Kruszwicy (Sawicka w opracowaniu), Międzyrzeczu (Sawicka, 2015). Pozostałości małych pracowni produkujących obrączki-kółka znaleziono na Morawach (Dolni Věstonice) i w Brnie (Černá, Tomková, Hulínský, 2015, s. 83-86). Na zachodzie Europy taka produkcja miała długie tradycje, wytwarzano pierścionki głównie ze szkieł wysokoołowiowych $\left(\mathrm{PbO}-\mathrm{SiO}_{2}\right)$ i ołowiowo-potasowych $\left(\mathrm{PbO}-\mathrm{K}_{2} \mathrm{O}-\mathrm{SiO}_{2}\right)$ w starych centrach wytwórczych czy warsztatach przyklasztornych (Stephan, 1987). Produkcja tych prostych ozdób, wykonanych ze szkła, którego wytworzenie było stosunkowo proste, szczególnie typu PbO-SiO2 (składnikami była glejta ołowiowa i piasek, a temperatura topnienia była niższa niż przy innych rodzajach szkła), mogła odbywać się w małych ośrodkach miejskich - takich jak np. XI-wieczny Lincoln (Bayley 2008).

We Wrocławiu takie pracownie wytwarzały z importowanego półsurowca szklane kółka, obrączki i pierścionki (Pankiewicz, Siemianowska, 2018, s. 161-162), podobnie w Kruszwicy, gdzie w poziomach osadniczych z XII w. odkryto duży zbiór głównie kółek i nielicznych półfabrykatów (Sawicka, 2018b). Nie można łączyć takich znalezisk z handlem dalekosiężnym, ponieważ powstawały w lokalnych warsztatach i były często dystrybuowane przez prężne miejscowe faktorie handlowe, takie jak w Berlinie-Spandau, gdzie handlowano zielonymi pierścionkami ze szkła ołowiowego (Wedepohl, 1998, s. 26).

Znajdowane na terenach Polski przebadane laboratoryjnie okazy również były wykonane z dwóch odmian szkła ołowiowego, zwykłe kółka przeważnie z wysokoołowiowego, bezalkalicznego typu $\mathrm{PbO}-\mathrm{SiO}_{2}$, obrączki zdobione wtopioną nitką z żółtego opakowego szkła - przeważnie ze szkła ołowiowego alkalicznego $\left(\mathrm{PbO}-\mathrm{K}_{2} \mathrm{O}-\mathrm{SiO}_{2}\right)$.

Liczne znaleziska z Anglii (Hereford, Gloucester, Lincoln, Oxford, Winchester, York, Londyn), jak i z terenów Polski lub w mniejszym stopniu z ówczesnej Rusi Kijowskiej, a rzadkie ze stanowisk skandynawskich wskazują na dwa duże obszary dystrybucji (i produkcji) - w Anglii i przede wszystkim na terenach zasiedlonych przez Słowian (znaleziska z Berlina-Spandau, Brandenburgii, Schwedt, regionu Łaby-Saale, a także obszarów Turyngii i Saksonii: Stepphun, 1998, s. 78).

Funkcję pierścionka-obrączki-kółka postrzega się zazwyczaj w sposób bezpośredni jako biżuterię, ozdoby włosów, aplikacje. Niekiedy łączy się takie znaleziska z tkactwem (Černa, 1981). Proste kółka z nieprzezroczystego ciemnego szkła, odkrywane niekiedy gromadnie na terenach zachodniej Polski, Niemiec i Czech, występujące w pierwszej połowie późnego średniowiecza, uznaje się za drobny niemonetarny pieniądz (Olczak, 2000, s. 317; Dzieduszycki, 1995) lub jego namiastkę (bliżej Olczak, 2009). Takie kółka mogły być produkowane w małych warsztatach, przez kontraktowego rzemieślnika (np. jedna z pracowni w Międzyrzeczu: Sawicka, 2015). 
Konkludując. Wytwarzanie wyrobów ze szkła jest procesem dwuetapowym, w pierwszy etapie odbywa się wytop masy szklanej z surowców wyjściowych, w następnym - kształtowanie, formowanie przedmiotów z lepkiej masy oraz ich wykańczanie, ewentualne zdobienie i w końcu studzenie. Te procesy nie muszą występować razem w jednym miejscu i czasie. Większość szklanych ozdób wykonywano ze sprowadzanego gotowego szkła lub półfabrykatów w warsztatach przetwórczych, często przez różnych i w dużej mierze nieznanych, niekiedy wędrownych rzemieślników. Ich wyposażenie było proste i przenośne, z niezbędnymi piecykami lub prostymi piecami zbudowanymi na miejscu. Odkryte podczas badań wykopaliskowych często nie są rozpoznawalne, bowiem niewiele po nich pozostało, z wyjątkiem przepalonej gliny. Jeśli towarzyszą takim znaleziskom odpady z produkcji ozdób, zapasy szkła - lokalne, importowane lub poddawane recyklingowi, jak fragmenty naczyń, możemy mówić o pozostałościach takiego warsztatu. Znajomość rodzajów i typów szkła, technik wytwarzania szklanych ozdób, czy informacje pomagające określić występowanie, przede wszystkim paciorków, nie wystarczają, aby prześledzić drogę takiego przedmiotu. Powszechny handel wszelkiego rodzaju półproduktami szklanymi w średniowieczu oraz import wyrobów szklarskich do różnych regionów Europy pozostawiają takie rozważania na etapie założeń. Zabytki ze szkła, przede wszystkim paciorki, ujawniają mozaikę średniowiecznych więzi handlowych, politycznych, kulturalnych, religijnych i etnicznych.

Od okresu karolińskiego (połowa VIII - IX w.) organizacja produkcji szklarskiej w Europie Zachodniej i basenie Morza Bałtyckiego jest zbadana i czytelna. Zaczęto stosować lokalne surowce do produkcji szkła potasowego (pracownie typu A - wytwórcze, huty), jednocześnie lokalne warsztaty przetwórcze (pracownie typu B) importują surowe szkło sodowe często z ośrodków bliskowschodnich, również w postaci stłuczki czy półproduktów, takich m.in. jak pałeczki millefiori do produkcji elitarnych paciorków mozaikowych (warsztaty przetwórcze w Haithabu, Ribe, Åhus, Groß Strömkendorf) (Matthes, Heck, Theune, Hoffmann, Callmer, 2004, s. 120). Ośrodki, w których odkryto takie pracownie, były również wielkimi faktoriami handlowymi, gdzie handlowano też gotowymi, importowanymi wyrobami. Takim ośrodkiem było Haithabu, działające do XI w., które kumulowało towary napływające zarówno z Zachodu (szkło z imperium frankijskiego), Północy, jak i ze Wschodu - napływające nie tylko wielkim szlakiem północnym, ale również różnymi szlakami południowymi (McCormick, 2007, s. 587). Do przełomu XI i XII w. szklane paciorki napływające na ziemie polskie szlakiem północnym, przez Ruś, można łączyć z warsztatami orientalnymi - bizantyńskimi czy arabskimi (głównie obszar Syrii czy Palestyny). W pewnym stopniu Bizancjum pełniło rolę pośrednika w handlu islamskimi wyrobami ze szkła. Paciorki islamskie niektórych typów od VIII w. zdominowały handel w basenie Morza Bałtyckiego i wyparły wyroby miejscowych warsztatów (Callmer, 2003, Sode, 2010). Od przełomu XI i XII w. zaczynają prężnie działać i eksportować warsztaty Rusi Kijowskiej. Analizy niektórych paciorków z Gniezna wpisują się w trudną dyskusję o wędrówkach i zależnościach, surowcach, półsurowcach, technologiach, rzemieślnikach. 


\section{PODSUMOWANIE}

Biżuteria szklana z ośrodka grodowego w Gnieźnie jest zbiorem pochodzącym z różnych faz jego rozwoju i stanowi grupę o znacznym stopniu zróżnicowania. Materiał pochodzi z kilku stanowisk wieloczłonowego grodu. Nie jest liczny, jak można się spodziewać po tak wielkim ośrodku, na co mają zapewne wpływ późniejsze, trwające prawie tysiąc lat prace budowlane. Najwięcej zabytków ze szkła dostarczyły przedwojenne, szerokopłaszczyznowe badania podgrodzia III w zasięgu stanowiska $13 \mathrm{~b}$. Mimo braku zaginionej w czasie wojny części dokumentacji, najnowsze ustalenia chronologiczne, oparte na datowaniach $14 \mathrm{C}$, uszczegółowiły datowanie i pozwoliły wydzielić jednoczasowy zbiór zabytków pochodzący z poziomów osadniczych między połową w. X a pierwszą poł. w. XI ( istotną datą jest najazd na Wielkopolskę w 1039 roku wojsk czeskiego księcia Brzetysława). Analizy składu chemicznego niektórych gnieźnieńskich okazów umożliwiły, obok oznaczenia grupy technologicznej i typu szkła, podjęcie próby określenia ewentualnego pochodzenia surowca wyjściowego - szkła.

Wczesny wczesnośredniowieczny horyzont osadniczy (przedgrodowy lub z okresu budowy grodu - druga ćwierć X w.) reprezentuje paciorek oliwkowaty z metalową tuleją wokół kanalika, pochodzący z terenów byłego państwa wielkomorawskiego, ale prawdopodobnie nie tam wyprodukowany(ryc. 4: 5). Wczesną metrykę mogą mieć oba cylindryczne paciorki wykonane z pałeczek millefiori, zdobione ornamentem kwiatowym, pojawiające się w Europie na początku IX w. (ryc. 4: 3, 4) oraz paciorki ze ,złotą" wkładką odkryte w poziomie osadniczym z trzeciej ćw. X w. (ryc. 3: 18-20).

W poziomach osadniczych z połowy w. X - pierwszej poł. w. XI pojawiają się paciorki, wprawdzie $\mathrm{w}$ niewielkiej ilości, ale reprezentujące typy zarówno łączone $\mathrm{z}$ pracowniami nadbałtyckimi, jak i pracowniami bliskowschodnimi - bisier, mikropaciorki obu typów, paciorki melonowate, segmentowe i segmentowe z metalową wkładką, ze szkła barwionego związkami kobaltu, zdobione kratką (jagodowe), trójkątne.

Przebadane laboratoryjnie okazy bisieru (szkło sodowe, popiołowe różnych odmian) pozwoliły na porównanie $z$ innymi przebadanymi okazami z ziem polskich $\mathrm{i}$ określenie przypuszczalnego pochodzenia - z pracowni przetwórczych (B) z terenów nadbałtyckich, w tym może z pracowni w Wolinie. Paciorek-zawieszka wykonany ze szkła sodowego, mineralnego, paciorek jagodowy i okazy „trójkątne” wykonane ze szkła ołowiowo-krzemowego, bezalkalicznego, badacze łączą z pracowniami bliskowschodnimi.

Znaleziska obrączek-kółek, które w ośrodku gnieźnieńskim nie są precyzyjnie datowane, należy łączyć raczej z XI w. i okresem późniejszym. Brak analiz tych egzemplarzy nie pozwala, jak dotąd, na porównanie ich składu z egzemplarzami odkrytymi w nieodległej Kruszwicy, gdzie najprawdopodobniej produkowano proste kółka w warsztatach jubilerskich z końca XI/początku XII w. i w dużym warsztacie - hucie (?) z drugiej połowy XII w. 
Relacja geografa arabskiego al-Idrisiego, że w grodzie gnieźnieńskim „mają być zebrane dostatki z rozmaitych krajów i rzemieślnicy biegli w swoim rzemiośle" (Lewicki, 1945, s. 142-143) znajduje niejako potwierdzenie w materiale zabytkowym z Gniezna. Wprawdzie nie odkryto dotąd cmentarzyska szkieletowego, rzędowego, związanego z okresem pierwszej dynastii piastowskiej, jednak najprawdopodobniej cmentarzysko takie musiało istnieć, lecz dotąd jeszcze nie natrafiono na jego pozostałości ${ }^{14}$. Przypuszczalne wyposażenie zmarłych w ozdoby szklane, pochowanych w tej nekropoli, mogłoby w znaczący sposób poszerzyć naszą wiedzę. Mimo braku takich materiałów, przedstawiona wyżej mała cząstka rzeczywistych zasobów niewątpliwie świadczy o zamożności mieszkańców wczesnośredniowiecznego kompleksu osadniczego w Gnieźnie.

\section{BIBLIOGRAFIA}

Andrałojć, M.

2015 Wczesnopiastowskie cmentarzysko rzędowe w Gołuniu, gm. Pobiedziska, woj. wielkopolskie. Studia Lednicke, 14, 15-176.

Arbman, H.

1940 Birka, t. 1: Die Graber. Tafeln - Uppsala: Almaqvist \& Wiksells Boktryckeri Artiebolag.

Bayley, J.

2008 Lincoln. Evidence for Glass-working on Flaxengate and Rother sites in the city. Technolo-

Bronicka-Rauhut, J. gy Report. Research Departament Report (Series 68).

1998 Cmentarzysko wczesnośredniowieczne w Czersku. Warszawa: Wydawnictwo Naukowe Semper.

Bukowska-Gedigowa, J., Gediga, B.

1986 Wczesnośredniowieczny gród na Ostrówku w Opolu. Polskie Badania Archeologiczne, 25 .

Callmer, J.

1977 Trade beads and bead trade in Scandinavia ca. 800-1000. Acta Archaeologica Lundensia $4 / 11$.

Callmer, J.

1997 Beads and bead production In Scandinavia and the Balic Region c. A.D 600-1100, a general outline. W: U. von Freeden, A. Wieczorek (red.), Perlen. Archäeologie, Techniken, Analysen (s. 97-202). Bonn: Dr Rudolf Habelt GmbH.

2003 Beads in Scandinavia in the Early and High Medieval periods, ca. 400-1200. W: I. C. Glover i in. (red.), Ornaments from the past: Bead studies after Beck (s. 38-46). London: The Bead Study Trust.

Chmielowska, A.

1960 Wyroby szklarskie z X-XIII w. na stanowisku 1 w Gdańsku. W: J. Kamieńska (red.). Gdańsk wczesnośredniowieczny, t. 3 (s. 105-157). Gdańsk: Ossolineum.

${ }^{14}$ Zdaniem Tomasza Sawickiego z Muzeum Początków Państwa Polskiego w Gnieźnie, autora większości badań archeologicznych z lat 1981-2015, pozostałości poszukiwanego cmentarzyska mogą się znajdować na terenie należącym do kościoła św. Wawrzyńca i częściowo ulicy o tej samej nazwie (stan. 77). Świadczą o tym znaleziska pojedynczych zabytków, m.in. paciorka szklanego o wczesnym datowaniu (ryc. 4: 1) oraz kilku ostróg żelaznych z pierwsze połowy XI w. i czterech kabłączków skroniowych. 
Černá, E.

1981 Sklenene kroužky-prstýnki z Prahy 1-Klárova. Archeologické rozhledy, 33(40), 393-397.

Černá, E., Tomková, K., Hulínský, V.

2015 Proměný skel od 11. do konce 13. století v Čechach. Archeologické rozhledy, 67, 79-108. McCormick, M.

2007 Narodziny Europy. Korzenie gospodarki europejskiej 300-900. Wydawnictwo Naukowe PWN.

Dekówna, M.

1970 Uwagi o funkcji i pochodzeniu niektórych wczesnośredniowiecznych przedmiotów szklanych znalezionych na terenie Polski. Studia z dziejów rzemiosła i przemystu, t. 10 (s. 21-45). Wrocław - Warszawa - Kraków: Ossolineum.

1980 Szkło w Europie wczesnośredniowiecznej. Wrocław - Warszawa - Kraków - Gdańsk: Ossolineum.

1987 Essai de clasification et d'interpretation des vestiges de la production du verre provenant des sites archéologiqes antiques et du haut Moyen Âge. W: Annales du $10^{e}$ Congrés de l'Association Internationale pour l'Histoire du Verre; Madrid-Segovie 23-28 septembre 1985 (s. 207-220). Amsterdam.

1999 Glass beads. W: H. Zoll-Adamikowa, M. Dekówna, E. M. Nosek (red.), The Early Mediaeval hoard from Zawada Lanckorońska (upper Vistula River) (s. 25-70). Warszawa: Institute of Archaeology and Ethnology Polish Academy of Science.

2005 Rozwój metod badania znalezisk szkła w Polsce. Acta Universitatis Nicolai Copernici, (Seria Archeologia, 29) Archeologia szkta, 9, 3-40.

Dekówna, M., Olczak J. (red.)

2002 Principes de description des verres ancien depuis les temps les plus reculés jusq'au XIII siécle de n.é. Warszawa - Torun: Wydawnictwo DiG.

Dekówna, M., Purowski, T.

2012 Znaleziska związane ze szklarstwem oraz okazy z kwarcu ze stanowiska Janów Pomorski. W: M. Bogucki, M. F. Jagodziński (red.), Janów Pomorski stan. 1. Wyniki ratowniczych badań archeologicznych w latach 2007-2008, t. 1, cz. 3: Analizy (s. 66-260). Elbląg: Muzeum Archeologiczno-Historyczne w Elblągu.

2016 Paciorki szklane. W: A. Buko (red.), Bodzia. Elitarny cmentarz z początków państwa polskiego (s. 153-206). Warszawa: Wydawnictwo Instytutu Archeologii I Etnologii PAN.

2019 Biżuteria szklana z cmentarzyska w Dziekanowicach. W: J. Wrzesiński (red.), Groby z biżuteria wczesnośredniowiecznego cmentarzyska w Dziekanowicach (s. 261-358) (Fontes. Biblioteka Studiów Lednickich, seria B1, t. 8: 1). Lednica: Muzeum Pierwszych Piastów.

Delvaux, M. C.

2017 Patterns of Scandinavian Bead use between the Iron Age and Viking Age, ca. 600-1000

C. E. Beads. Journal of the Society of Bead Researches, 29, 3-30.

Drahotova, O. (red.)

2005 Historie sklářské výroby v českých zemich, t. 1. Praha: Academia.

Dzieduszycki, W.

1995 Kruszce w systemach wartości i wymiany spoleczeństwa Polski wczesnośredniowiecznej. Poznań: Instytut Archeologii i Etnologii PAN.

Farkaš, Z., Turčan, V.

1998 Včasnostredoveká sklárska pec v Bratislave na Devínskej Kobyle. Slovenská Archeológia, $46(1), 31-54$.

Filarska, B.

1952 Szkta starożytne, t. 1. Warszawa: Muzeum Narodowe w Warszawie.

Galibin, W. A.

2001 Sostav stiekła kak archieołogičeskij istočnik. Ars vitraria experimentalis. Sankt-Peterburg:

Peterburgskoe Vostokovedene. 
Galuška, L.

2017 Slované-stopy predků. O Moravé v 6.-10. Stoleti. Brno: Moravské zemske museum.

Gaut, B.

2011 Vessel Glass and Evidence of Glassworking. W: D. Skre (red.), Things from the Town. Artefacts and Inhabitants in Viking-age (Kaupang Excavation Project Publication. Series 3). Norske Oldfunn, 24.

Hrubý, W.

1955 Staré Město. Velkomoravské pohřebiště „Na Valách”. Praha: Nakladatelstvi Ceskoslovenské Akademie VĚD.

Jaskanis, D.

2009 Święck. Wczesnośredniowieczny zespót osadniczy na pótnocno-wschodnim Mazowszu. Białystok: Stowarzyszenie Naukowe Archeologów Polskich Oddział w Warszawie, Muzeum Podlaskie w Białymstoku.

Kaźmierczyk, J.

1970 Wrocław Lewobrzeżny we wczesnym średniowieczu, cz. 2. Wrocław - Warszawa - Kraków: Ossolineum.

Koch, U.

1997 Polychrome Perlen in Würtenberg/Nordbaden. W: U. von Freeden, A. Wieczorek (red.), Perlen, Archeologie Techniken. Analysen (s. 143-148). Bonn: Dr Rudolf Habelt $\mathrm{GmbH}$.

Kociszewski, L.

1966 Metody laboratoryjne badania przedmiotów zabytkowych ze szkła. Studia z dziejów rzemiosta i przemystu, 6, 49-75.

Kóčka-Krenz, H.

1997 Biżuteria średniowieczna na ziemiach polskich jako wyznacznik chronologiczny. Archaeologica Historia Polona, 6, 69-75.

Kokora, K.

2019a Szklarstwo wczesnośredniowiecznego Wolina według Jerzego Olczaka i Elżbiety Jasiewiczowej - 55 lat później. Nowe ustalenia dotyczące przedmiotów szklanych ze stan. 1 w Wolinie. Archeologia Polski, 64, 283-338.

2019b Glass Artefacts. W: M. Rębkowski (red.), Wolin. The Old Town, t. 2: Studies on finds (s. 191-221). Szczecin: Wydawnictwo Instytutu Archeologii i Etnologii PAN.

Košta, J., Tomková, K.

2011 Olivovité korálky v raně středověkých Čechach a jejich postavení ve středoevropském kontextu. Památky Archeologické, 102, 307-353.

Kouřil, P. (red.)

2014 Great Moravia and the beginnings of Christianity. Brno: Archeologický ústav Akademie véd ČR.

Krukowska, O.

2015 Glass Ornaments as the Garment Decoration of Citizens of Early Medieval Gdańsk. W: O. Felczak (red.), The Baltic Sea - a Mediterranean of North Europe. In the Light of Archaeological, Historical and Natural Science Research from Ancient to Early Medieval Times (s. 93-100). Gdańsk: Scietific Association of Polish Archaeologist Gdańsk DiviKrumphanzlová, Z. sion, Gdańsk Archaeological Museum.

1965 Skleněné perly doby hradištni v Čechach. Památky archeologické, 56(1), 161-188.

Krzyżanowska, M., Frankiewicz, M.

2017 „Paciorki mozaikowe w otwartym palenisku?”. Kontynuacja badań. Slavia Antiqua, 58, 41-54.

Kuzina, I.

2016 Glass beads in the northern regions of Rus': issues of trade routes and chronology. Archeologia Polski, 61, 219-240. 
Lewicki, T.

1945 Polska i kraje sasiednie w świetle „Księgi Rogera” geografa arabskiego ab-Idrisiego, cz.

1. Kraków: Polska Akademia Umiejętności.

Markiewicz, M.

2008 Biżuteria szklana z wczesnośredniowiecznych cmentarzysk strefy chełmińsko-dobrzyńskie. Mons Sancti Laurenti, t. 4. Toruń: Wydawnictwo Naukowe Uniwersytetu Mikołaja Kopernika.

Matthes v C., Heck, M., Theune, C., Hoffmann, P., Callmer, J.

2004 Produktionsmechanismen frühmittelalterlicher Glasperlen. Germania, 82, 109-157.

Musianowicz, K.

1969 Drohiczyn we wczesnym średniowieczu. Materialy Wczesnośredniowieczne, 6, 7-228.

Nowotny, W.

1958 Szkta barwne. Warszawa: Arkady

Olczak, J.

1968 Wytwórczość szklarska na terenie Polski we wczesnym średniowieczu. Studium archeologiczno-technologiczne. Studia i materialy z historii kultury materialnej, 35 (Studia z dziejów rzemiosła i przemysłu, 8). Wrocław - Warszawa - Kraków: Ossolineum.

1995 Nowe materiały do dziejów użytkowania szkła na ziemiach polskich. Acta Universitatis Nicolai Copernici (Seria Archeologia, 22). Archeologia szkta, 6, 9-32.

1996 Problem wytwórczości szklarskiej na obszarze Wielkich Moraw (Mikulčice - Nitra Staré Město). W: Z. Kurnatowska (red.), Stowiańszczyzna w Europie średniowiecznej, t. 2 (s. 143-154).Wrocław: Wydawnictwo „Werk”.

2000 Średniowieczne szklane pierścionki-obrączki-kółka. Kilka uwag o technice formowania i funkcji. W: L. Kajzer (red.), Archeologia et historia. Księga jubileuszowa dedykowana Pani Profesor Romanie Barnycz-Gupieńcowej (s. 311-322). Łódź: Instytut Archeologii Uniwersytetu Łódzkiego.

2009 O sposobach użytkowania niektórych wczesnośredniowiecznych wyrobów ze szkła. Folia Praehistorica Posnaniensia, 15, 249-263.

Olczak, J., Jasiewiczowa, E.

1963 Szklarstwo wczesnośredniowiecznego Wolina. Szczecin: Muzeum Pomorza Zachodniego.

Pankiewicz, A., Siemianowska, S.

2018 Czy na Wrocławskim Ostrowie Tumskim w X-XIII w. istniały pracownie szklarskie. Ślaskie Sprawozdania Archeologiczne, 60(2), 141-165.

Pankiewicz, A., Siemianowska, S., Sadowski, K.

2017 Wczesnośredniowieczna biżuteria szklana z głównych ośrodków grodowych Śląska (Wrocław, Opole, Niemcza). In pago Silensi. Wrocławskie Studia Wczesnośredniowieczne, t. 3. Wrocław: Uniwersytet Wrocławski Instytut Archeologii.

Pöche, A.

2005

Beiträge zur Ur- und Frühgeschichte Perlen, Trichtergläser, Tesserae. Spuren des Glashandels und Glashandwerks auf dem Frühgeschichtlichen Handelplatz von Groß Strömkendorf, Landkreis Nordwestmecklenburg. Mecklenburg Vorpommerns Band, t. 44. Schwerin.

Poulik, J.

1948 Staroslovanska Morava. Monumenta Archaeologica, t. 1. Praha: Státni archaeologický ústav.

Purowski, T.

2012 Wyroby szklane w kulturze tużyckiej w międzyrzeczu Noteci i środkowej Odry. Studium archeologiczno-technologiczne. Warszawa: Wydawnictwo Instytutu Archeologii i Etnologii PAN.

2013 Wyroby ze szkla $i$,,szklistego fajansu” odkryte na cmentarzysku kultury lużyckiej i regionalnej grupy kręgu halsztackiego w Domasławiu, pow. wrocławski. Archeologia Polski, 58, $23-87$.

2019 Od fajansu do szkła. Kontakty ziem polskich z głównymi centrami cywilizacyjnymi w II-I tys. p.n.e. w świetle badań archeometrycznych tworzyw szklistych. Warszawa: Wydawnictwo Instytutu Archeologii i Etnologii PAN. 
Robertshaw, P., Benco, N., Wood, M., Dussubieux, L., Melchiorre, E. and Ettachiri, A.

2010 Chemical analysis of glass beads from Medieval Basra (Morocco). Archeometry, 52, 365-379.

Rzeźnik, P.

1998 Paciorki szklane z wczesnośredniowiecznego grodziska w Gostyniu na Dolnym Śląsku. W: W. Łosiński, H. Kóčka-Krenz (red.), Kraje stowiańskie w wiekach średnich. Profanum i Sacrum (s. 380-391). Poznań: Wydawnictwo Poznańskiego Towarzystwa Przyjaciół Nauk.

Sawicka, J.

2015 Średniowieczne pracownie szklarskie w Międzyrzeczu. Slavia Antiqua, 56, 125-166.

2016 Paciorek „oliwkowaty” z metalową tuleją. W: B. Gruszka (red.), Wczesnośredniowieczny gród w Polupinie, stan. 2. Nowe analizy i interpretacje źródeł archeologicznych i przyrodniczych (s. 29-38). Zielona Góra: Wydawnictwo Fundacji Archeologicznej w Zielonej Górze.

2017 Biżuteria szklana z wczesnośredniowiecznego zespolu osadniczego w Miliczu [maszynopis w archiwum OSPiŚ IAE PAN w Poznaniu].

2018a Pozostałości średniowiecznych szkieł okiennych. W: T. Sawicki (red.), Gniezno. Wczesnośredniowieczny zespót grodowy (s. 341-354) (Seria Origines Polonorum, 12). Warszawa: Wydawnictwo Instytutu Archeologii i Etnologii PAN.

2018b Czy w Kruszwicy wytapiano szkło? Z badań nad wytwórczością szklarską w Kruszwicy. W: M. Brzostowicz, T. Kasprowicz, M. Przybył, J. Wrzesiński (red.), Od Popiela do Kazimierza Wielkiego. Księga dedykowana Wojciechowi Dzieduszyckiemu (s. 103-114). Poznań: Wydawnictwo Instytutu Archeologii i Etnologii PAN.

2019 Zabytki ze szkła. W: K. Zamelska-Monczak (red.), Santok strażnica i klucz królestwa polskiego. Wyniki badań z lat 1958-1965 (s. 258-276) (Seria Origines Polonorum, 13). Warszawa: Wydawnictwo Instytutu Archeologii i Etnologii PAN.

Sawicka, J. (w opracowaniu) Grant NPRH 1aH 15041983 pt.: Mit, tradycje i rzeczywistość materialna.

Ščapova, J. L.

Kruszwica. Od wczesnopiastowskiego grodu do zamku kazimierzowskiego.

1973 Zasady interpretacji analiz składu szkła zabytkowego. Archeologia Polski, 18(1), 15-72.

1998 Bizantijskoje stiekto. Očerki istorii. Moskva: Editoriał URSS.

Siegmann, M.

1997 Die Perlen des Frühmittealterlichen Gräberfeldes von Liebenau. W: U. von Freeden,

A. Wieczorek (red.), Perlen. Archeologie. Techniken. Analysen (s. 133-142). Bonn:

Dr Rudolf Habelt GmbH.

2006 Bunte Pracht - Die Perlen der frühmittelalterichen Gräberfelder von Liebenau, Kreis Nienburg/Weser, und Dörverden, Kreis Verden/Aller, teil 5. Beiträge zur Ur- und Frühgeschichte Mitteleuropas, t. 28. Langenweissbach: Beier\&Beran. Archäologische Fachliteratur.

Sode, $\mathrm{T}$.

2004 Glass bead making technology. W: M. Bencard, A. Kann Rasmussen, H. Brinch Madsen (red.), Ribe Excavations 1970-76, t. 5 (s. 83-102). Aarhus: Aarhus Universitetsforlag.

2010 An investigation on segmented, metal-foiled glass beads and blown, mir-rored glass beads from Ribe, Denmark. In: C. Dobiat, P. Ettel und F. Fless, Zwischen Fjorden und Steppe. Festschrift für Johan Callmer Zum 65 (Geburtstag. Internationale Archäologie Studia honoraria, 31), 219-328.

Staššikova-Štukovská, D., Plško, A., Kucera, M.

2007 "Granulácia” zo skla a ,vlasový efekt” technológie 7.-8. storočia? Historické sklo. Sbornik pro dějiny skla, t. 4 (s. 17-26). Čelákovice: Mětske museum v Čelákovicích.

Stawiarska, T.

1984 Szkła z okresu wpływów rzymskich z pótnocnej Polski. Studium technologiczne. Wrocław - Warszawa - Kraków - Gdańsk - Łodź: Ossolineum. 
1987 Metody porównań składów chemicznych szkieł zabytkowych ze szczególnym uwzględnieniem okresu wpływów rzymskich. Acta Universitatis Nicolai Copernici (Seria Archeologia, 12). Archeologia szkta, 2, 35-50.

Stephan, H. G.

1987 Mittelalterliche Glasfunde aus Höxter/Weser. Bulletin de L'association internationale pour l'histoire du Verre, 7, 158-166.

Steppuhn, P.

1997 Bleiglasperlen des Frühen und hohen Mittelalters in Nordeuropa. W: U. von Freeden,

A. Wieczorek (red.), Perlen. Archeologie. Techniken. Analysen (s. 201-209). Bonn:

Dr Rudolf Habelt GmbH.

1998 Die Glasfunde von Haithabu. Berichte über die Ausgrabungen in Haithabu. Bericht, t. 32. Neumünster: Wachkoltz Verlag.

Szilágyi, K.

1994 Perlentypen aus dem X-XII. Jahrhundert in Ungarn und ihre Archäologische bedeitung. Památky archeologické, 85, 75-110.

1997 Beiträge zur Frage des Perlenhandels im 10.-12. Jahrhundert im Karpatenbecken. W: U. von Freeden, A. Wieczorek (red.), Perlen. Archeologie. Techniken. Analysen (s. 233242). Bonn: Dr Rudolf Habelt GmbH.

Tait, H. (red.)

1995 The thousand years of glass. London: British Museum Press.

Theune, C.

2008

Die Perlen von Dunum - Neue Forschungen zur Chronologie des karolingerzeitlichen Gräberfeldes von Dunum, Ldkr. Wittmund (243ff). Probleme der Küstenforschung im südlichen Norseegebiet, 32.

Urllich, D. G.

1989 Halbedelsteine und Glasfunde. W: A. von Müller, K. von Müller-Mčci (red.), Ausgrabungen, Funde und naturwissenschaftliche Untersuchungen auf dem Burgwall in BerlinSpandau (s. 57-99). Berlin: Wissenchaftsverlag Volker Spiess

Valiulina, S.

2016 International trade relations of the middle Volga region in the Medieval Period through the glass evidence. Archeologia Polski, 61,113-170.

Venclová, N.

2016 Němčice and Staré Hradisko. Iron Age glass and glass-working in Central Europe. Praha: Archeologický ústav AV ČR.

Wajda, S.

2013 Zabytki szklane i szkliwione. W: J. Kalaga (red.), Sutiejsk. Gród pogranicza polsko-ruskiego z X-XIII wieku. Studium interdyscyplinarne. Warszawa - Pękowice: Wydawnictwo Profil-Archeo.

Wedepohl, K. H.

1998 Mittelalterliches Glas in Mitteleuropa: Zusammensetzung, Herstellung, Rohstoffe. Göttingen: Vandenhoeck\&Ruprecht in Göttingen.

Wieczorkowski, T.

1939 Zabytki ze szkła, szkliwa, kamieni półszlachetnych, bursztynu itd. z Gniezna. W: J. Kostrzewski (red.), Gniezno w zaraniu dziejów (od VIII do XIII wieku). Poznań: Poznańskie Towarzystwo Prehistoryczne.

Wrzesińscy, A. i J.

1995 Dwa interesujące groby z wczesnośredniowiecznego cmentarzyska szkieletowego w Dziekanowicach, gm. Łubowo, woj. poznańskie, stan. 22. Wielkopolskie Sprawozdania Archeologiczne, 3, 207-218. 
Zbierski, A.

1959 Wczesnośredniowieczne materiały archeologiczne z Czermna nad Huczwą. Archeologia Polski, 4, 105-148.

Zakharov, S. D., Kuzina I. N.

2008 Veshchevoi material Mininskogo arkheologicheskogo kompleksa: Izdeliya iz stekla i kamennye busy. W: Arkheologiya severnorusskoi derevni 10-13 vekov: srednevekovye poseleniya i mogil'niki na Kubenskom ozere, t. 2 (s. 142-215). Material'naya kul'tura i khronologiya. Moskva: Nauka.

Żak, J.

1957 Kwestia pochodzenia szklanych paciorków odcinkowych na ziemiach pomorskich. Materiaty Zachodnio-Pomorskie, 3, 161-174.

\title{
THE ISSUE OF CHRONOLOGY, TYPOLOGY AND ORIGIN OF GLASS JEWELRY FROM THE EARLY MEDIEVAL SETTLEMENT IN GNIEZNO
}

\author{
Su m mary
}

The article presents a small collection of glass jewelry (169 beads and 6 rings) from many years of research (from 1938 to the present) on the early medieval settlement center in Gniezno. The materials come from several sites of a multi-part hillfort on the Lech Mountain (Fig. 1) and from the cemetery at the present St. Lawrence. The majority of the collection comes from the site 13b, III borough, the youngest member of the settlement complex, investigated in 1936-1938. The last radiocarbon findings, implemented under the NPRH grant (Clarification and verification of the chronology and periodization of the so-called central monarchies of the first Piasts »Gniezno, Poznań, Giecz« based on accelerator radiocarbon dating), were helpful in dating the settlement levels of the stronghold.

Several groups of beads were distinguished, using the technique of their manufacture as the overriding criterion of division: beads formed from a pulled tube (group 1), by winding a glass strand on a mandrel (group 2) and individual specimens made by casting and sintering (group 3). In these groups, types differing in size or ornamentation, referring to generally accepted classifications, were distinguished. Only 7 beads were tested in the laboratory using the XRF (X-Ray Fluorescence) method.

The most numerous group are small beads manufactured with two clear techniques:

- pull-out and cut tube (group 1). These are bisier type beads and segment beads, including those with a metal insert. The laboratory-tested bisiers were made of soda-ash-glass of the $\mathrm{Na} 2 \mathrm{O}-\mathrm{K} 2 \mathrm{O}-\mathrm{CaO}-\mathrm{MgO}-\mathrm{A} 12 \mathrm{O} 3-\mathrm{SiO} 2$ variety,

- winding the glass strand on the mandrel (group 2). Here, several basic types are distinguished - the most numerous are microbeads: flat, made by a single curl of a glass strand and conical, carelessly made specimens, mainly from necklaces (fig. 2.1). Such a laboratory-tested bead was made of lead non-alkali glass of the PbO-CaO-SiO2 variety. Group 2 also includes single specimens of beads - spiral, barrel-shaped (including those with a metal insert), a two-conical pendant made of soda-lime-glass of the $\mathrm{Na} 2 \mathrm{O}-\mathrm{CaO}-\mathrm{SiO} 2$ variety, a large ring-shaped bead, two melon beads - one of the specimens made of soda ash glass of the Na2O-K2O-CaO-SiO2 variety, triangular beads decorated with plastic nodules, a cylindrical bead decorated with a plastic ornament of an engraved grid, a square bead and an 
olive-shaped bead with a metal stem around the canal. A separate type in this group is represented by four beads decorated with the millefiori ornament (fig. 4.1-4). One of the samples tested in the laboratory was made of Low Magnesium Glass of the Na2O-PbO-CaO-SiO2 variety. The form of the bead and the type of glass it was made of allow it to be associated with the Hallstatt period.

Group 3 consists of two single specimens - a rare raspberry-shaped bead made by casting technique (fig. 4.7) and a small square bead made by sintering of lead non-alkali glass of the $\mathrm{PbO}-\mathrm{SiO} 2$ variety (fig. 4.6).

From all the sites in the Gniezno center, only 5 partially preserved glass circles come from. Archival analysis allows to determine the glass from which one of the specimens was made as lead-alkali glass of the $\mathrm{PbO}-\mathrm{K} 2 \mathrm{O}-\mathrm{SiO} 2$ variety.

Recent chronological findings allowed, in some cases, a more accurate dating of the settlement levels from which the presented specimens come.

The mosaic bead from the Hallstatt period (fig. 4.1) comes from the medieval cemetery at the church of St. Lawrence, lying outside the strict area of the settlement. However, the existence of an earlier site (a cemetery from the Hallstatt period?) in this area should not be ruled out. The Great Moravian olive-shaped bead comes from the construction period of the first fortifications (2nd quarter of the 10th century) (fig. 4.5). More glass jewelery comes from the later settlement levels, from around 940-983 to 1039, mainly from the 3rd borough (site 13b). These are beads of the bisier type and microbeads of both types (fig. 2), segmental beads also with a metal insert, a spiral bead (fig. 3.1-14), beads with a "golden" insert (fig. 3.18-20) and a pendant / spindle (fig. 3.31). A rare specimen of a raspberry bead may come from a level dated to the mid-11th century. In the horizons dating from the 10th century to the beginning of the 12th century, two dark sapphire glass beads (fig. 3: 21, 22), a sintering bead and a "millefiori" bead (fig. 4.3) were discovered. A large part of the collection comes from the rubble layers or generally dated to the 10th-13th centuries. This also applies to finds of circles, their presence in Gniezno can be traced back to the second quarter of the 11 th century at the earliest.

Physicochemical analyzes of the chemical composition of some specimens made it possible, in addition to marking the technological group and the type of glass, to attempt to explain the origin of the starting material - glass. A comparative analysis made it possible to indicate in a general manner of possible producers and to outline the likely directions of the influx of glass ornaments to Gniezno. They can be combined both with large production centers of the Baltic Sea basin (millefiori beads, bisier, segment beads) and with oriental Middle East workshops (triangular beads, with a "golden" insert), from where they could flow along the northern route through Russia. From the turn of the 11 th/12th century, glass workshops in Rus started to operate, from where the semi-raw material for the production of rings-rings could come from.

Early medieval Gniezno was one of the most important centers of the Piast state. Its comprehensive development covers the period from around the middle of the 10th century to the 12th century. It was a stronghold accumulating goods flowing in from the nearby large trade routes. The small collection of glass jewelery presented in this article is probably a small fraction of the actual resources. 